\title{
Covid-19 - Medya Okuryazarlığı ve Çocuklar Üzerine Etkileri
}

\author{
NILÜFER PEMBECIOĞLU
}

Özet

Bu çalışma, COVID-19 olarak bilinen korona virüs yayılımı öncesinde ve sonrasında Türkiye ve Dünya ölçeğinde çocukların nasıl etkilendiğini ele almaya çalışmaktadır. Bu çalışma, dünya ölçekli bir pandemi ve kısıtlılık sürecinde çocukların yüklendikleri bireysel ve toplumsal roller ile, karşılaştıkları engelleri ve yaşamlarında iz bırakabilecek bu engelleri nasıl aşabildikleri ile ilgili değerlendirmeler içermektedir. Bu çalışma, sınırları önceden çizilen 'Yeni Normal' ile çocukların nasıl bağlantılandırılması gerektiğine odaklanmayı amaçlamaktadır. Öngörülen değerlendirmeler çerçevesinde, her ne kadar günümüzde yetişkinlerden ve çocuklardan, farklı yaşam standartlarından ve yaşam beklentilerinden söz ediliyor olsa da, "COVID-19 ve Pandemi" açmazına odaklanan bu çalışma ele alınan metin çözümlemeleri ve zaman zaman metin içi söylem çözümlemeleri, metin dışı referanslar ve $12 \mathrm{~K}$ yöntemiyle ele alınan sorunları ortaya koyabilmeyi amaçlamaktadır.

Anahtar kelimeler: COVID-19, pandemi, çocuklar, medya okuryazarlığı

\begin{abstract}
- ARASTIRMA MAKALESI-

NILÜFER PEMBECIOĞLU, niluferpembecioglu@gmail.com

İstanbul Üniversitesi İletișim Fakültesi Radyo Sinema Televizyon Bölümü ORCID: https://orcid.org/0000-0001-7510-6529

This study aims to handle the impact on how the children in Turkey and worldwide were effected throughout the process known as the corona virus spread and lockdown. The study includes assessments regarding the individual and social roles the children undertook during the world-wide pandemic, as well as the strategies they made use of on the way to overcome the obstacles 
they faced that might leave a temporary or permanent mark in their lives. Even if there could be different living standards and life expectancies in adults and children, the aim of the paper mainly is to question how children should be conjoined with the predetermined 'New Normal'. Dwelling more on "Covid19 and Pandemic" dilemma, the paper aims to reveal problems focusing on the framework of the foreseen evaluations, the text analysis and occasional discourse analysis exemplified with non-text references and the $12 \mathrm{~K}$ methodology discussed

Keywords: COVID-19, pandemic, children, media literacy

\section{Giriş}

2020 yılına ait pek çok bilimsel çalışma, COVID-19 üzerine odaklı olacak gibi görünüyor. 2019 itibariyle ilk olarak Çin'in Wuhan kentinde ortaya çıktığı iddia edilen ve bugüne kadar dolaşımda olan diğer 'corona' virüslerden farklı olan yeni koronavirus, COVID-19 kavramı çok hızla belleklerimize kazınan bilgi ve görüntülerle yaşamımızda önemli bir yer edindi. Üzerinden geçen onca zaman sürecinde medya her gün yeni vakalardan, korunma yollarından söz ederek, olası yeni tedavi yolları ve aşı arayışlarını gündeme getirdi. Halen, her yeni gün bu yeni hastalıkla ilgili bilgiler akmaya, bu hastalığın belirtileri, hastalıktan korunma yöntemleri, yayılımı, virüsün yaşam döngüsü, hangi ortamlarda yaşayabildiği, nasıl ve ne kadar hızla yayıldığı, kimlere daha kolay bulaştığı gibi konularda ortaya çıkan her tür veri paylaşıldı ve paylaşılmaya devam ediyor. Pandemi süreci, geleneksel medya kadar sosyal medyada da kendine önemli bir yer edindi ve çeşitli bilgilendirme biçimleri daha geniş ve özel bir çerçevede yayılımını sürdürdü.

COVID-19'un dünya çapında yarattığı panik, değişen değerler dizgesi ve dünyaya sunulan yeni düzen hakkında oldukça uzun bir zaman daha konuşulacak gibi görünmektedir. Tam olarak olan bitenin farkına varabilmek ise, sıradan insanlar için biraz daha zaman alacak gibi görünmekle birlikte, daha önceden, 1950'lerden bu yana medya iletileri ile körüklenmekte olan "Kötü Dünya Sendromu"nun yeniden iş başında olduğu ileri sürülebilir. Ancak, 1950’lerden günümüze gelindiğinde, işler biraz daha farklı görünüyor, çünkü, o dönemlerdeki gibi yalnızca televizyon ya da sinema gibi rüya satan eğlenceliklerin dışında çok daha gerçekçi ve somut biçimde

Çocuk ve Medeniyet 2020/1 algılanan bir medya erişimi ve dağılımı söz konusu. Bunca çeşitlenen medyadan toplumlara ulaşan iletilerin ise gerçek anlamda bir korku ve endişe kaynağı olmaya devam etmekte olduğu da görülmektedir. 
Güncel istatistiki bilgilere göre, örneğin 16 Haziran 2020 tarihi itibariyle dünya vakalarındaki ölümlerin 450 bini aştı̆̆ $1^{1}$, Türkiye genelinde toplam 2.674.203 kişiye test yapıldığı ve toplam 179.831 vaka ile karşılaşıldığı bunlardan toplam 4.825 kişinin yaşamını yitirdiği, çeşitli merkezlerde toplam 722 kişinin yoğun bakım hastası, 291 kişinin ise entübe hasta olarak halen tedavi görmekte olduğu belirtilmektedir ${ }^{2}$. 12 Mart 2020 tarihi itibariyle Türkiye genelinde başlayan pandemi sürecinde toplam iyileşen hasta sayısının ise 152.364'ü bulması sevindiricidir ${ }^{3}$.

Pandemi sonrası gelecek beklentilerini ortaya koyabilmek için, öncelikle pandemi öncesinde ve pandemi sürecinde neler olup bittiğinin iyice anlaşılması, çözümlenmesi gerekmektedir. Bu nedenle, bu dönemin, medya ve çocuklar bakış açısı ile irdelenmesi, somut çıktılarının ortaya konulması gerekmektedir. Çocukların medya karşılaşmaları her zaman ilginç sonuçlar ortaya koymaktadır ancak pandemi sürecine verdikleri karşılık, çocukların artık büyüdüklerinin ifadesi anlamını taşımaktadır.

\section{Yöntem ve Amaçlar}

COVID-19 tanılamaları ve dünya çapında başlayan pandemi çerçevesinde, her ülkenin kendi özelinde öngördüğü önlemler çerçevesinde, bireyler ve toplumlar olarak evlerde kalmaya ve her türlü sosyal, iktisadi, eğitsel eylemlere ara vermeye zorlandığımız bir dönem yaşandı. Bu dönemde yaşanılanlar, öğrenilenler, deneyimlenenler ve hissedilenler pek çok insanda geçici ya da kalıcı izler bıraktı. Bu çalışma çerçevesinde, bu süreci daha bilimsel bir bakış açısı ile irdeleyebilmek için $12 \mathrm{~K}$ modeli ile bir olgu değerlendirmesi yapılabileceği düşünülmüştür. Çalışmanın yöntemi olarak seçilen 12K yaklaşımı, 1997'de Stoller \& Grabe tarafından İçerik-Tabanlı Öğretime ilişkin “6T’s Approach" olarak adlandırılan bir değerlendirme yaklaşımıdır. 2012'de Pembecioğlu tarafından yapısal, içeriksel ve işlevsel bir metin çözümleme tekniği olarak geliştirilmiş olup, ele alınan her bir $\mathrm{K}$ (Kategori), incelenen örnek metnin, olgu ya da durumun farklı bir bakış açısı ile değerlendirilmesi anlamına gelmekte, böylelikle, anlatının, durumun ya da olgunun tutarlılığını ve uyumunu ele almaktadır. Bu tür bir çözümlemede asıl amaç, araştırılan olgunun ya da durumun, metnin içeriğini, işlevini ve konumunu ortaya koyan çözümleyici bir formüle

1 http://www.gazeteilksayfa.com/dunya-genelinde-kovid-19-nedeniyle-olenlerin-sayisi450-bini-asti-76979h.htm

2 https://www.haberturk.com/son-dakika-koronavirus-salgininda-bugunun-yeni-vakasayisi-1467-2714597

3 https://www.haberturk.com/corona-virusu 
ulaşmaktır. Günümüzde, birçok film çözümleme araştırmasında kullanılan 12K (12T) yaklaşımı, anlamın ve görüntünün, kültürün ve kodların çeşitli amaçlarla nasıl farklı şekillerde betimlendiğini sorgulamakta önemli bir araç işlevi yüklenmektedir. Çalışmanın temel amacı ise, yaşanılan sürecin nesnel ve göstergesel bir çözümlemesini sunabilmek, bu çözümleme içinde çocuklara ilişkin kodların neler olduğunu, bu kodların onları nasıl etkilediğini irdeleyebilmektir. Bu bağlamda tüm değerlendirmeler, yalnızca Türkiye için değil küresel ölçekte değerlendirilebilir.

\section{Bulgular ve Değerlendirmeler}

Her zaman diliminde ve her olguda dile getirildiği ve getirileceği gibi, medya okuryazarlığı son derece önemli bir kavram olup, her zaman, her şekilde, her bir birey için gitgide artan bir öneme sahiptir. Medya Okuryazarlı̆̆ı, pandemi öncesinde de önemli bir kavramdı, pandemi sürecinde de önemini korudu ve arttırdı, ancak özellikle pandemi sonrasındaki zaman dilimlerinde gitgide artan bir öneme sahip olacağ kesindir.

Bu çalışmanın bulgular ve yorum kısmında, 12K yaklaşımına göre ele alınması planlanan kategoriler değerlendirilmektedir. Özetle Kavram, Konu, Kurmaca, Katıştırma, Konuşlandırma, Karşıya Geçişler \& Kabuller, Karşılamalar, Kavrama ve Karar Verme, Katılım, Kriz Çözümleri, Kurallar ve Teknolojik Olanaklar, Kayganlık kategorileri ele alınarak bunlarla ilgili çıkarımlar serimlenecektir.

\subsection{Kavram (Theme): COVID-19 Pandemi}

Bu kategoride ele alınan şey, bir temel olarak üzerinde durulan 'Kavram'dır, bu yüzden, temel kavramı görebileceğimiz bir bakış açısının ortaya konmasını gerekli kılar. Kimilerine göre sağlık bir kavram olarak ele alınabilir, kimilerine göre ise COVID-19 temel bir kavramdır. Temel kavramın ne olduğunu ve nasıl saptanabileceğini tartışmak bile son derece önemlidir. Ancak, olgular üzerinden hareket edilmesi gerektiğinde, bu araştırma çerçevesinde ele alınan temel kavramın 'Pandemi' kavramı olması gerektiği düşünülmektedir. Tarihte pek çok salgın hastalık yaşanmış ve bunların pek çoğu, beraberlerinde belki de onlarca savaştan daha fazla can kaybına neden olan felaketler getirmişlerdir. İnsanlık tarihi boyunca pek çok hastalık salgın hastalığa dönüşmüş ve salgın hastalıklar nedeniyle ölenleri sayısı ortalama 250 milyonu bulmuştur. Örneğin, 1347-1351 yılları arasında görülen büyük veba salgını, Avrupa'da birkaç yılda 100 milyona yakın kişinin hayatını kaybetmesine ve daha sonra da kıtlığa ve ardından 
kalıcı göçlere sebep olmuştur. Salgın her ne kadar öncelikle yoksul ve bakıma muhtaç insanlarda ortaya çıkmış ise de, gitgide üst tabakadaki kesimin de etkilenmesi kaçınılmaz olmuş, hatta Babil seferinden dönen Hitit Kralı I. Şuppililuma'nın, Aragon Kralı 4. Pedro ve eşi Leanor'un, İngiltere Kralı 3. Edward'ın kızı Jon'un adları kurbanlar arasında anılmaktadır. Veba salgını Avrupa'daki pek çok ülkeyi aynı anda etkilediği için, etkisi çok yıkıcı olmuştur. Kayıtlara göre, tüm Avrupa nüfusunun üçte birinin vebaya kurban verildiği görülmektedir. Örneğin, İtalya'da Cenova, Floransa, Messina ve Venedik gibi kentlerde nüfusun \%75'den fazlasının veba salgınından öldüğü bilinmektedir. Fransa'da 125.000, İngiltere de 1.000 .000 kişi ölmüss, Suriye, Lübnan, Mısır, Hatay, Mekke, Yemen ve daha pek çok yerde, yaşayanların büyük bir kısmı hayatını kaybetmiştir. Süreç içinde, hastalığın suçlusu olarak görünen pek çok farklı düşman üretilmiş (Yahudiler, cadı ve büyücü olmakla suçlanan kadınlar, kediler, dilenci ve çingeneler) ve ölenler yüzünden bunlar suçlanıp cezalandırılmıştır.

Salgın sonuçları açısından vebadan geri kalmayan bir başka hastalık cüzzam ise, XV. yüzyıla kadar Avrupa'da, bir hastalık değil Tanrı'nın bir gazabı olarak tanımlanmaktaydı. Bu nedenle, cüzzamlıyı da hasta değil büyücü ya da lanetli olarak gören insanlar, onları ya hapseder ya da onlardan kaçarlardı. Cüzzamın bir hastalık olduğu fikri ancak 1403 yılında Venedik'te kurulan ilk leprosarium dönemi ile başlamaktaydı. Bu tarihten önce cüzzamlılar sağlıklarıyla birlikte mal varlıklarını da kaybetmişler ve dışlanan bu insanlar toplumda yeni bir sınıf oluşturmuşlardı. Herkes tarafından hor görülen cüzzamlıların umuma ait yerlere girmeleri yasaklandığı gibi halkın kendilerinden uzaklaşmasını sağlamak için dolaşırken çıngırak çalmaları da zorunlu kılınmıştı. VII. Louis'in vasiyetnâmesinden, cüzzamlıların hapsedildiği yerlerin sayısının Fransa'da 2000, bütün Hıristiyanlık âleminde ise $\mathbf{1 9 . 0 0 0}$ olduğu öğrenilmektedir.

Birinci Dünya Savaşı'nın son aylarında tüm dünyayı etkisi altına alan İspanyol gribi, kimi tarihçilere göre dört yıl süren savaşın sona ermesinde önemli bir etken olmuştu. İlk kez 11 Mart 1918'de ABD'nin New Mexico eyaletinde tespit edilmesiyle, bir salgına dönüşerek 1918 Eylül-Kasım aylarında zirve noktasına ulaşmış ve Türkiye dahil tüm dünya ülkelerini etkilemişti. Askerî sansür nedeniyle diğer Avrupa devletlerinde salgından hiç söz edilmezken savaşta yer almayan İspanyol basınının salgın konusunu ilk kez gündeme getirmiş olması, hastalığın İspanyol gribi olarak 2020/1 adlandırılmasına neden olmuştu. Ancak, dünya çapında yayılan hastalıktan en fazla ölenler Asya ve Afrikardaydı. Asyardaki bir hastanın ölüm ihtimali Avrupa dakinin 30 katıydı. İlk belirtiler arasında solunum güçlüğü ortaya çıkıyor, hastaların yüzü kızıl kahve bir renk alıyor, bu renk daha sonra 
maviye dönüyor, insanlar öldüklerinde ise simsiyah oluyorlardı. Ölüm nedeni çoğu vaka açısından gribin kendisi değil, virüsün akciğerde açtığı yaralara yerleşen bakteriler sonucu oluşan zatürreydi. Hastalık sürecinde, hastalarda diş ve saç dökülmesi de oluyor, baş dönmesi, uykusuzluk, görme ve işitme kaybından şikâyet ediyorlardı. Hayatta kalanlar virüs enfeksiyonu sonrası oluşan depresyon geçiriyordu.

Sıtma hastalığı da, zaman zaman bireysel olarak görülmesine karşın, tarihte salgın olarak pek çok ülkede birden görünen hastalıklardan biridir. Hastalığı ilk defa bildirenler Eski Mısırlılar'dır. M.Ö. 460-370 yıllarında Hipokrat da bataklık bölgelerde tekrarlayan ateş ve dalak büyüklüğüyle seyreden bir hastalığı fark etmiş ve dört ayrı şekilde olabileceğini not almıştır. Torti (1753) ateşli hastalıklar için yazmış olduğu kitabında ilk defa 'Malaria' adını kullanarak sıtmayı diğer hastalıklardan ayrı olarak ele almış, 1894'te Manson sıtmanın sivrisineklerle bulaştığını ortaya çıkarmıştır. Eski çağlarda kitleler hâlinde ölüme sebep olan sıtma bugün de bu tehlikesini halen sürdürmektedir. Tarihe bakıldığında, I. Dünya Savaşı'ndan sonra Rusya'da 5 milyon sıtma hastası olduğu ve bunların 60.000'inin öldüğü belgelenmektedir. Benzer şekilde, 1934'te Seylan'da 3 milyon sıtmalının 100.000'inin yaşamını yitirdiği, Amerika kıtasındaki ilk salgının 1938'de Brezilya'da ortaya çıktığı ve 100.000 sıtma hastasının 14.000'inin öldüğü bilinmektedir. 1942'de Nil Vadisi'nde görünen sıtma salgınlarının Mısır'da 12.000 kişiyi öldürdüğü ve Etiyopya'da 15.000 kişinin ölümüne, 1963'te Haiti'de 75.000 kişinin ölümüne neden olduğu da bilinmektedir.

Asya ve Afrika kökenli çiçek hastalığının 11, 12 ve 13. yüzyılda özellikle Fransa ve İtalya'da tahribata yol açan Avrupa salgınlarının temelinde Hıristiyan hacılar olduğu söylenir. Çoğunlukla kızıl, suçiçeği ve frengi ile karıştırılan çiçek hastalığı, günümüzde aşı ile yok edilmiş durumdadır. Çok uzun yıllardır bir tür doğal bağışıklama olan sağlam kişilerin çiçek hastasının deri döküntüleri ile yapay olarak hastalandırıldığı yöntemi; Çinliler, Hintliler İranlılar ve doğu Afrika halkları kullanmışlardır. 1763 yılında İngiliz General Sir Jeffrey Amherst sürekli ‘sorun çıkaran' Kızılderililerden kurtulmak için onlara çiçek virüsü bulaştırılmış olan battaniyeler hediye etmiş ve bunlar da bütün bir Cheyenne kabilesinin sonunu getirmişti.

Her biri birbirinden korkunç vakalarla anılan, günümüzdeki deyimi ile pandemi, dünyanın çeşitli zaman dilimlerinde hep benzer görüntülere sebep olmuştu. Aslında, Corona Virüs'ün kısaltılmasıyla elde edilen "COVID” sözcügü dünya çapında bir dil birliği için kullanılmaya başlandı. Aslında bu türde pek çok virüs daha önce de vardı ve pek çok vakaya neden olmuştu. Ancak, yeni bir suşe olarak tanımlanan COVID-19 hastalığının 11 Mart 
tarihi itibarıyla Dünya Sağlık Örgütü tarafından pandemi olarak tanınması nedeniyle dünya bambaşka bir döneme girmiş oldu. DSÖ 11 Mart tarihinde, COVID-19 olarak tanımlanan bu virüsü salgını sebebiyle 114 ülkede 118 bin vakaya rastlandığı, 4 bin 291 kişinin ise hayatını kaybettiğini açıklamasının ardından, COVID-19'un pandemik hastalıklar grubuna dahil edildiği duyurdu ${ }^{4}$. Pandemi; dünyada birden fazla ülkede veya kıtada, çok geniş bir alanda yayılan ve etkisini gösteren salgın hastalıklara verilen genel bir isimdi. Enfeksiyondan korunma ve kontrol önlemlerini uygulayarak; enfeksiyonun toplumda yayılmasını azaltmak ve böylece pandeminin erken dönemlerinde enfekte olacak kişi sayısını ve pandemi nedeniyle ortaya çıkacak vakaları azaltmak mümkündü.

Pandemi sürecini tanımlamak gerektiğinde, medyadan aldıkları bilgiler çerçevesinde herkesin herkesten, en yakınlarından bile fiziksel ve duygusal olarak uzaklaştığı bir izolasyon süreci olarak değerlendirmek mümkündür. Medya bağlamında ise, haber kavramının adeta yeniden şekillendiği, basının ve tüketicilerin adeta bir hızlı haber alma-verme yarışına girdiği inanılmaz boyuttaki haberlerin dünyanın dört bir yanında üretildiği ve tüketildiği bir pandemi sınırlılığı süreci yaşandığı görülmektedir. İnsanların, her türlü işten güçten arındırılıp, izole bir biçimde evlerinde yaşamak ve dünyayı medya aracılığı ile izlemek durumunda kaldığı uzunca bir zaman dilimi içeren bu dönemin geçici ya da kalıcı izleri olacağı kesindir. Çok şükür, yurt dışında bazı ülkelerde olduğu gibi yaşlıların bakımevlerinde toplu ölümleri ya da sokaklarda bakımsızlıktan ölen insan görüntüleri Türkiye bağlamında ortaya çıkmamıştır. Bu, tümüyle toplumun hem bir yandan birbirine daha bağlı olan sosyal yapısından, hem de aile büyüklerine daha çok saygı ve hürmeti öngörün geleneksel yapısından kaynaklanmaktadır denilebilir.

Çocukların pek çoğu açısından, pandemi öncesi dönem ve pandemi süreci, kendi çocuklarına ve torunlara anlatabilecekleri ilginç deneyimlerle dolu hassas, duygusal bir dönem olacaktır. Hangi çocuğun bu dönemi nasıl algıladığını şu anda tam olarak bilememize karşın, onların daha sonra bu konu ile ilgili bakış açılarının ortaya konması, öykülerinin tam da can alıcı noktasını oluşturmaktadır. Çünkü hiçbir eylem sıcağı sıcağına ölçüldüğünde somut, saydam ve tarafsız değildir. Ancak, üstüne eklenen başka anılar, duyumlar ve duygulanımlar ile çocukların bu dönemi öykülendirme biçimleri üzerinde durulması gereklidir. Yaşamlarında belki de ilk ve tek defa karşılaştıkları bu pandemi sürecini kendilerine nasıl tanımladıkları ve gelecekte nasıl tanımlayacakları, olduğu gibi mi saklayacakları, yoksa

Çocuk ve Medeniyet 2020/1
4 https://www.sabah.com.tr/yasam/2020/03/20/pandemi-nedir-neden-ilan-edilir-dsotarafindan-pandemi-ilan-edilen-hastaliklar-hangileri 
süreç içinde yaşadıkları korkularını, kaygılarını yok mu sayacakları, bunları sıradanlaştırıp normalleştirdikleri mi yoksa abartıp farklı değerlerle zenginleştirdikleri mi zaman içinde ortaya çıkacaktır.

\subsection{Konu (Topic): Medya Okuryazarlığı ve Çocuk}

Pandemi kavramı çerçevesinde pek çok konu gündeme gelmiştir, daha nicesi gündeme gelebilir. Konu kategorisi, genel anlamda, ele alınan metinlerin ya da temel olguların hangi konu bağlamında değerlendirildiğini ortaya koymayı amaçlamaktadır. Çünkü aynı kavramdan hareketle, çok farklı 'konu' başlıklarının ortaya çıkabilmesi mümkündür. Bu çalışmada, konu olarak medya okuryazarlığı ve çocuk konusu seçilmiş olup, ilgili kavram çerçevesinde konunun nasıl geliştiği irdelenmektedir.

Metin ve olgu incelemelerinde, "konu" söz konusu olduğunda, öncelikle DSÖ'nün pandemi açıklaması ile karşı karşıya bulunulan durumun ciddiyeti ve boyutu ile ilk kez somut olarak karşılaşılmış olduğu ortaya çıkmaktadır. Öncelikle vurgulanması gerekir ki, COVID-19 ile ilgili bulgular ve bilgiler, hastalığın yayılması ile ilgili duyurular ve korunma tedbirleri her bir bireyin gerçek anlamda bir medya okuryazarı olması gerekliliğini bir kez daha ortaya koymaktadır. Bu gelişme ile birlikte medya okuryazarlığı konusu ciddi bir biçimde gündeme gelmekteydi. Çünkü, ikinci dünya savaşından bu yana dünya çapında bir salgın hastalıkla karşılaşmayan 21. yüzyıl bireyleri ve toplumları için pandemi sözcüğü belki de hayatlarında ilk kez karşılaştıkları bir kavramdı; buna ve gereklerine hiç de hazırlıklı değildiler.

Aslında, tam da pandemi söz konusu olduğu dönemde, dünya çapında on çocuk ve ergenden altısının eğimin minimum şartlarını yerine getiremediğini, yani okuyup yazamadığını vurgulamak gereklidir. Bu da pandemi şartlarında bile bu bireylere gerekli bilginin ve korunma yöntemlerinin sağlıklı olarak aktarılamaması anlamına gelmektedir. Daha da vahim olan durum ise, küresel anlamda, on çocuk ve ergenden altısı, okuma ve matematikte minimum yeterlilik seviyesine ulaşmamakta olması, 6-11 yaş arasındaki çocukların yarısından fazlasının okuryazarlık ve matematik (neden-sonuç ilişkisi) yeterliklerini karşılayamaması anlamına gelmektedir. En vahim durum ise, bu oranların yalnızca çocukları edilgen ve zayıf kılmaması, yetişkinleri de içermesidir. Küresel anlamda, ergenlerin de \%61'inin bir ortaöğretim mezunu olmalarına karşın okuryazarlık ve matematik gereklerini yerine getiremeyecek bilgi ve işlev düzeyinde olduğunu vurgulamak gereklidir (Unesco, 2017). Bu da, belki de DSÖ’nün ya da kendi toplumlarındaki yöneticilerin dediklerini anlama ve yerine getirme sorunu olan 617 milyon çocuk ile 230 milyon ergen anlamına 
gelmektedir. Bilindiği gibi, okuryazarlık, temel bir beceridir ve nüfusun eğitiminin önemli bir ölçütüdür. Tarihsel bir perspektiften bakıldığında, dünya nüfusu için okuryazarlık seviyeleri son üç yüzyılda büyük ölçüde artmıştır. 1820'lerde dünyadaki insanların yalnızca \%12'si okuyup yazabilirken, bugün bu oran tersine dönmüştür: Dünya nüfusunun sadece \%17'si okuma yazma bilmemektedir (https://ourworldindata.org/literacy). Temel eğitimin genişlemesine ve eğitimdeki eşitsizliklerin sürekli olarak azalmasına karşın, dünyadaki en fakir ülkeler, hala okur-yazar olmayan nüfusun çok büyük bölümlerine sahiptir. Örneğin Nijer'de, gençlerin okuryazarlık oranı (15-24 yaş) sadece \%36.5'tir.

Medya okuryazarlığı, yalnızca görsel, işitsel imgelerin bir medya aracılığı ile kamusal alana sunulması anlamına gelmez, bu iletilerin anlaşılmasını ve gereklerinin yerine getirilmesini de içeren daha geniş bir perspektifi de beraberinde taşır. Örneğin, pandemi nedeniyle, 25 Nisan 2020'de sokağa çıkma yasağı ilan edildiğinde 20 yaş altı 40 bin 77 kişi ile sosyal mesafe kurallarına uymayan 37 bin 78 kişiye idari para cezası kesilmesi ${ }^{5}$, aslında toplam 77.155 kişinin medya okuryazarı olmadığı anlamına gelmektedir. Bu, yalnızca medyadan ilan edilen sokağa çıkma yasağını değil, hukuk ve sağlık ile ilgili kavramlara ilişkin bir ihlali de beraberinde taşıyan bir okuryazarlık eksikliğidir. Çünkü, yasağı ihlal edenler, Türk Ceza Kanunu'nun Bulaşıcı Hastalıklara ilişkin Tedbirlere Aykırı Davranma başlıklı 195. maddesinde yer alan "Yetkili makamlarca alınan tedbirlere uymayan kişi iki aydan bir yıla hapis cezası ile cezalandırılır" hükmü uyarınca, işlem başlatılacağını da bilmeyen/umursamayan bir tutum izlemiş olmaktadırlar. Benzer şekilde örneğin maske ya da eldiven kullanımı gibi diğer konularda da ihlaller olduğunda temel bir okuryazarlık eksikliği düşünülmelidir.

Pandemi sürecindeki bilgilendirmenin en sağlıklı yapıldığı bu zaman diliminde $^{6}$, Dijital okuryazarlık da pandemi sürecinde son derece önemli bir boyuta taşınmış durumdadır. Bireylerin yaşadıkların yerlerin güvenliğini ve kendi sağlık durumlarını sorgulayabilecekleri telefon uygulamalarının bakanlık düzeyinde uygulamaya konulduğu bir noktada, dijital okuryazar olmayanların, internet erişimi bulunmayanların büyük sorunları olacağı anlamı çıkmaktadır. Bunun dışında, hangi yaş grubunun sokağa çıkma ya da kent dışına çıkma izni olduğu, e devlet üzerinden ya da HES kodu ile izin alma işlemleri de tümüyle dijital vatandaşlığı ve dijital okuryazarlığı gerektiren bir noktada durmaktadır.

81

Çocuk ve Medeniyet 2020/1
5 https://www.hurriyet.com.tr/gundem/37-bin-kisiye-mesafe-cezasi-41503013

6 https://www.webtekno.com/turkiye-sahte-haberlere-en-cok-guvenen-ulke-oldu-h48103. html 
$\mathrm{Bu}$ arada, hemen belirtilmesi gereklidir ki, ulusal ve uluslararası medya, çocukların medya okuryazarlıklarını göz önünde bulundurarak hem çocuklara hem de yetişkinlere hitap edecek, uzmanlar tarafından hazırlanıp, yetkili makamlar tarafından onaylanmış duyuru ve bilgilendirme içerikli yayınlar yapmaya başlamıştır ${ }^{7}$. Bu yayınlar, gerek hastalığın ne olduğu ve nasıl yayıldığı gerekse koruma tedbirleri ile ilgili uygulamaları içeren görsellerle hemen her yaştaki bireyleri hastalık riskine ilişkin uyarmayı hedeflemişlerdir ${ }^{8}$. Dünya televizyonlarının yayınladığı çeşitli dillerdeki kamu spotları, bunların içerdiği siyah, beyaz, sarı tenli çocuklar, konunun ne kadar evrensel olduğunu dile getirmeyi başarmıştır. Bu tür kamu spotlarının sıklığı ve içerdiği bilgilerin yoğunluğu, hemen tüm dünyada hastalığın tanınmasını ve alınması gerekli önlemler çerçevesinde eşgüdümlü hareket edilmesinin önemini ortaya çıkarmıştır.

Son bulgular pek çok bireyin, COVID-19'un yayılmasını durdurmak için evde kalmayı seçerek, kimi zaman resmi kimi zaman da gayri resmi bir izolasyon yaşamayı seçtiğini göstermektedir. İpsos'un küresel anlamda gerçekleştirdiği araştırmada, yalnızca hükümetlerin önlem almadığı aynı zamanda bilinçli (medya okuryazarı) vatandaşların da çoğunlukla kurallara uyup evde kaldıkları ve ülkelerin çoğunda kendi kendini izole etme uygulamasının iyi şekilde karşılandığı görülmektedir. İzolasyon uygulamasında en fazla artış gösteren ülkeler Rusya, Vietnam ve Avustralya olmasına karşın, farklı ülkelerdeki bireylerin büyük bir çoğunluğu, COVID19'un yayılmasını durdurmak için evde kendilerini izole ettiklerini veya karantinaya aldıklarını ifade ediyorlar. Bunlar arasında Japonların bir istisna olduklarını, Japonya'dan araştırmaya katılan bireylerin yalnızca \%15'inin pandemiyle mücadele etmek için evlerinde kaldıklarını belirtmek gerekir ${ }^{9}$. Her beş kişiden dördünün kendine gönüllü sosyal izolasyon uyguladığı İspanya, sosyal izolasyonu en yüksek oranda uygulayan ülkeler arasında başı çekmektedir. Oranlara bakıldığında, İspanya (\%95), Vietnam (\%94), Fransa (\%90), Brezilya (\%89), Meksika (\%88), Rusya (\%85), ABD ve Hindistan (\%84)'ın yüksek oranda izolasyon uyguladığı görülmektedir.

Ancak buradaki en önemli şey, tam da yaşamlarında en çok hareketliliğe ihtiyaç duydukları dönemde çocukların pandemi nedeniyle fiziksel olarak dışarı çıkmalarının engellenmesi, çocukların yalnızca fiziksel açıdan değil düşünsel açıdan da kısıtlanması, bir anlamda yaratıcılıklarının engellenmesi

82

Çocuk ve Medeniyet 2020/1
7 https://www.bbc.com/turkce/haberler-dunya-52224832

8 https://bit.ly/2NcIOWU

9 https://www.ipsos.com/tr-tr/koronavirus-salgini-ve-toplum-arastirmasi-4-donemdenone-cikanlar 
anlamına da gelmektedir. Çocukluğun doğası gereği, çocuk, yaparak, uygulayarak öğrenen ve gelişen bir yapıya sahiptir. Çocuğun fiziksel olarak belli bir mekâna sıkıştırılması, onun ruhunun ve bedeninin acı çekmesi anlamına gelir. Kollarının, bacaklarının oynaması, ellerinin, gözlerinin yeni nesnelere dokunması gereklidir. Ancak, pandemi durumu çocuğun hareket etmekten bile korktuğu hatta engellendiği bir ortam yaratmaktadır. Temel olarak, çocuğun en büyük korkusu, sevdiklerinin, aile bireyleri ile arkadaşlarının hatta evcil hayvanlarının sağlı̆̆ı konusundaki korkudur. Fiziksel olarak iyi şartlarda olsa bile, bu korkular yüzünden çocukların uyku düzeninde sık sık uyanma, kâbuslar görme, uykuya dalmada güçlük gibi karşımıza çıkabilecek uyku sorunları olabilir. Ayrıca çocuğun yeme örüntüsünde değişiklikler ortaya çıkabilir. Çocuğun aniden iştahsızlaşması, yemek yemek istememesi ya da istemsiz yeme krizlerine girmesi de söz konusu olabilir. Bu şartlar altında çocukluk çağı obezitesine de diyabete de dikkat etmek gerekir. Pandemi döneminde çocukların atıştırmalıkların dozunu biraz fazla kaçırdığı ve anne babaların da onları yatıştırmak amacıyla buna göz yumduğu görülmektedir. Bulgular, ikinci ve üçüncü haftada (18 Mart - 1 Nisan 2020); hanelerin alışveriş sepetlerinde en çok artış gösteren kategorilerin farklılaştığını ve atıştırmalık ürünlerin büyük bir artış gösterdiğini ortaya koymaktadır ${ }^{10}$.

Çocukların pandemi sürecine uyumu çerçevesinde, kısıtlanmanın getirdiği fiziksel ve bilişsel engeller, genel anlamda çocuğun odaklanmasında güçlükler şeklinde de baş gösterebilir. Çocuktan çocuğa değişebilecek şekilde farklı davranış değişiklikleri de ortaya çıkabilmektedir. Genel anlamda çocuklar içinde bulundukları bu belirsiz, çelişkili ve karmaşık durum nedeniyle kendilerini gergin ve bunalmış hissedebilir, tutarsız ya da uyumsuz davranabilir, asileşebilirler. Bütün bunlar aslında bize, anne, baba, benim kaygılarım, endişelerim var, lütfen benimle ilgilenin demektedir. Ancak, yetişkinlerin de bu dönemde onlara odaklanacak enerjileri kalmamış gibidir. Gördükleri ve şahit oldukları, maruz kaldıkları medya görüntüleri nedeniyle çocuklar kendilerini baskı altında hissedebilir, aynı soruları sorup cevap arayabilirler. Kontrol edilemeyen, hızlı ve tekrarlayıcı olumsuz düşünce örüntüleri ortaya çıkabilir. Aslında burada aradıkları yanıt, bilinmezlik, çaresizlik, güvensizlik gibi temel kavramlara dayanmaktadır. Sezgileri ile bulmuş oldukları bu sonuçların, yetişkinler tarafından da onaylanmasını ve değerlendirilmesini beklerler. Giderek, yalnızca içinde bulunulan durumun endişe verici etmenlerinden değil, sıradan, olağan şeylerden de kaygı,

Çocuk ve Medeniyet 2020/1 10 https://www.ipsos.com/tr-tr/koronavirus-salginiyla-ilgili-turkiyede-kamuoyu-ve-
tuketicinin-nabzi 
endişe ve korku duymaya kadar gidebilecek, geçici ya da kalıcı bir süreçtir bu! Genel anlamda içine kapanık, üzüntülü hissetme, ağlamaklı olma, keyif veren etkinliklere karşı ilginin azalması ya da sürekli bir yorgunluk hissi gibi olgularla karşılaşılabileceği belirtilmektedir (Loades, 2020).

Limbik sistemin gelişme aşamasındaki çocuklar sevdiklerinden aldıkları motivasyon ve tensel temas ile kendilerini sevgi dolu bir ortamda ve güvende hissederek büyükler. Bu temas ve motivasyon ortadan kalktığında ise, içe kapanık ve gelişmesine ket vurulmuş çocuklar gündeme gelecektir. Almaları gereken sevgi ve sosyal onay, çocuklar için yaşamsal düzeyde önemlidir. Dolayısıyla fiziksel olarak kısıtlandıklarında, kendilerini engellenmiş hissedebilirler, bu yüzden sinirlilik, öfke nöbetleri ya da ufak tefek huzursuzluklar hissedebilirler. Gevşeyememe/rahatlayamama sorunları ile karşılaşabilirler. Bilişsel olarak engellendiklerini hissettiklerinde ise genel anlamda bir umutsuzluk hissi, distopya ya da diğer bireylerden ya da sosyal çevreden kopmuş hissetme durumu ile karşılaşılabilir. Ancak, asıl temel sorun, bu fiziksel kısıtlılı̆̆ın çocuklukta çocukların ihtiyacı olan sevgi, ilgi, güven gibi kavramlarını da kısıtlamış olmasıdır. Pandemi sürecinde çocukların ve ergenlerin akranlarından, öğretmenlerinden, geniş aile ve toplum ağlarından uzak, uzun süreli bir fiziksel izolasyon yaşadığını kabul etmek gereklidir (Loades, 2020). Yetişkinlerde karantina koşulları genellikle karışıklık, öfke ve travma sonrası sıkıntı gibi olumsuz psikolojik etkilerin ortaya çıkmasına neden olabilir (Hossain, Sultana, Purohit, 2020). Ancak, karantina süresinin, enfeksiyon korkusu, can sıkıntısı, hayal kırıklığı, gerekli malzeme eksikliği, bilgi eksikliği, finansal kayıplar ve hastalanma riskinin olumsuz psikolojik sonuçlar oluşma riskini artırdığı görünmektedir (Brooks, Webster, Smith et al., 2020). Sosyal mesafe kuralları ile okulların kapanması ve öğretmenleri ile arkadaşlarını görememek, sevdikleri ve değer verdikleri aile büyüklerinden uzak kalmak, çocuklarda ve ergenlerde zihinsel sağlık sorunlarını artırabilir. Zaten sağlık tehdidi ve aile istihdamı / geliri tehditleri konusunda endişe duyduklarında çocukların ve gençlerin zihinsel sağlık sorunlarının tetiklenme ve artma riski yetişkinlere göre çok daha yüksektir (Deighton, Lereya, Casey, Patalay, Humphrey, Wolpert, 2019).

Çocuklar, ekran karşısında uzun süre kaldıklarında da benzer bir şey olmaktadır aslında. Günlük yedi sekiz saatini televizyon izleyerek geçiren çocukların, kaslarında, kemiklerinde, beyinlerinde gelişim bozuklukları ortaya çıkmaya başladığı bilinmektedir (Senek, Toz, 2019). Bu çocuklarda, (Damasio, 1992). Tümü bunların altında yatan neden, çocuğun hiçbir yaratıcılık girişiminde bulunmadan edilgen bir şekilde kendini akan bilgilere bırakmasıdır. Pandemi sürecinde böyle birkaç gün geçiren çocukların 
hepsinde elbette bu tür olumsuzlukların ortaya çıkacağını ve kalıcı izler bırakacağını iddia etmek, oldukça güçtür ancak bu olumsuzlukların engellenmesi de yine anne babanın çocuğu ile kuracağı olumlu diyaloğa dayanmaktadır. Burada, anne babaya düşen şey, çocuğun yaratıcılığını destekleyecek ortamın evin içinde yaratılması ve ona her gün yeni bilgi ve beceriler kazandırabilecek etkinlikler sunulmasıdır. Her bir çocuğun gelişim dönemine, duygusal ve fiziksel özelliklerine uygun tasarlanmış bu etkinlikleri çocukların anne babaları ve diğer aile üyeleri ile birlikte gerçekleştirmelerinden daha tedavi edici ne olabilir! Anne babaları ile birlikte yemek yapmak, birlikte kitap okumak, oyun oynamak aslında tüm çocukların özlemini çektiği şeylerdir. Çocuk, annesi ve babası ile yapılabilecek etkinlikleri bile farklı şekillerde sınıflandırmaktadır. Bu yüzden annenin ayrı, babanın ayrı ve anne-babanın ayrı ilgisi gündeme getirilmelidir. Ayrıca, bu ortamda kardeşlik ilişkileri de son derece önemli, büyük kardeşler daha küçük olanlar için, tıpkı anne babaları gibi rol model durumundadır. Ortak dinlenebilecek müzikler, muziplikler, şakalar, çocuğun yaşamın devam ettiğine ve olumsuzlukların biteceğini ilişkin inancını pekiştirmelidir.

\subsection{Kurmaca (Text): Pandemi ve Çocuk Kısıtlılığı}

Kavram ve konunun belirlenmesinden sonra, ne tür bir kurmaca metin ile bunların izleyicilere aktarıldığı sorgulanmalıdır. Aynı konu ile ilgili sayısız kurmaca metin üretilmesi söz konusu olabilir. Önemli olan bunlardan hangisine ya da hangilerine, neden odaklanılması gerektiğidir. Kurmaca söz konusu olduğunda, sözel, görsel ya da yazınsal her bir metin, özellikle bir medya ürünüyse mutlaka bir kurmaca içermektedir. Bu noktada, incelenen metindeki ya da olgudaki kurmacanın gerçek mi, mitsel mi yoksa uyarlama mı olduğu, metnin ya da olgunun kimin bakış açısından kurgulanmış olduğu gibi açılar önem kazanmaktadır. Pandeminin hemen herkesi hazırlıksız yakaladığı ve daha otoriter bir biçimde bireylere ve toplumlara ne yapmaları gerektiğini ileten, uyaran, denetleyen ve uymayanları tehdit eden hatta cezalandırılan bir bildirim söylemi bulunmaktadır. Dolayısıyla pandemi bağlamındaki kurmaca metinlerin genelde etkileşimli değil, tek yönlü bir bildirişim amacı taşıdığı söylenebilir. Üretilen bu söylem, olağanüstü hallerde uygulanıldığı gibi, tartışmaya yer vermeyecek şekilde kesin ve kuralcı yaklaşımlarla kamusal alanda paylaşılan bir 'yapılması gerekenler listesi' şeklindedir. Örneğin, ellerin yıkanması, maskelerin takılması, dezenfektan kullanılması, belli gün ve saatlerde ev dışına çıkılmaması 2020/1 gibi tüm bilgiler neredeyse tüm ülkelerde, medya tarafından bireylerle ve toplumla paylaşılmıştır. 
Bu paylaşımların yalnızca bazıları çocuk dili ile gerçekleştirilmiş haberleri ya da çocukların da anlayabileceği metinleri kapsamakta olup, genel anlamda çocukların pandemi ve getirdiği kısıtlamalardan anne-babaları ve evdeki diğer yakınları aracılığı ile haberdar olmalarının sağlandığı düşünülebilir. Medya iletilerinin kurmaca kısmının nadiren olayları ve olguları olduğu gibi ve nesnel olarak yansıttığı, ancak genelde bu bilgileri daha abartılı bir biçimde sunduğu ya da sıradanlaştırdığı göz önünde bulundurulduğunda, medya ile karşılaşan çocukların bu iletilerden büyük bir ihtimalle 'olumsuz' olarak etkilenmeleri söz konusudur. Kurmaca kısım, yalnızca sağlık ve devletle ilgili otoritelerin yayınladığı kamusal kısıtlamalardan ibaret değildir. Bu bölümde, hastalığın küresel anlamdaki seyri ile ilgili pek çok bilgi ve belge yayınlanmış, hemen her gün ülkemizde ve dünyanın tüm diğer ülkelerinde ne kadar vaka ile karşılaşıldığı, oradaki otoritelerin ve uzman görüşlerinin yer aldığı bilgilendirmeler, haberler, açık oturumlar ya da özel programlar aracılığı ile paylaşılmıştır. Kamusal yayın yapan ya da özel yayıncılık yapan televizyon, radyo ve internet kaynakları bu kurmaca kısmından payını almış, pandeminin ilan edildiği 11 Mart 2020 gününden itibaren normalleşmeye geçileceği belirtilen 1 Haziran 2020 tarihine kadar haftalarca aynı türde yayınlara devam etmişlerdir.

Kurmaca ile ilgili önemli bir başka konu da metinlerin bazılarının özellikle durum için üretilmiş, duruma ya da olguya uyumlandırılmış özellikler taşıyan metinler üretilebilme ihtimalidir. Bu çeşit kurmaca metinlerin özellikle yanlı bilgiler içeren, asılsız ve sahte haberler üretilmesini ya da mizah türü görseller ile sözcükleri değiştirilip "korona günleri”ne uyarlanmış müzikler içerebileceklerini de göz önünde bulundurmak gereklidir. Skeçler, gaglar, baloncuklarla yapılan konuşmalar gibi pek çok öğe, bireylerin kendilerinin de cep telefonları aracılığı ile üretebilecekleri metinler olduğundan, bu tür kurmacanın diğer didaktik metinlerden daha çok ilgi gördüğü ve daha fazla devindiği de gözden kaçırılmamalıdır.

Kurmaca ile ilgili en önemli kavramlardan biri de kurmacanın hangi medya aracılığı ile bize kadar ulaşabildiğidir. Metin, kamusal alanda mı dolaşmaktadır, rastlantısal bir biçimde mi karşımıza çıkmaktadır, yoksa onu diğer tüm metinler arasından biz mi arayıp bulmaktayız? Kaynak güvenilirliği konusu bizim metinle rastlantısal, bilinçli, seçici ya da yönetici bir biçimde karşılaşmamızı da sağlamaktadır. Rastlantısal metinler, izleyiciyi şaşırtabilir, hazırlıksız olduğu için şok edebilir, üzebilir. Bu

Çocuk ve Medeniyet 2020/1 durum, yetişkinler için önemlidir ancak çocuklar için çok daha fazla bir önem taşır. Anne babaları yeterince medya okuryazarı olmayan milyonlarca çocuk, medyadan kendilerine akan bilgiler, görüntülerle aslında rastlantısal 
olarak karşılaşmaktadırlar. Bilinçli seçimler ise ancak ne aradığını bilen bireylerin yapabilecekleri karşılaşmaları ortaya çıkarabilecektir. Örneğin, belli bir tarihte, belli bir ülkedeki vaka sayılarını bilmek isteyen bir çocuk ya da yetişkin, odaklanmış bir biçimde bu iletiyi belli türde bir medyada arayabilir. Seçici olmak ise daha üst düzey bir medya okuryazarlığı bilgi ve donanımı gerektirmektedir. Var olan binlerce haber, veri, bilgi arasından, hangisine güvenileceğini ${ }^{11}$, hangisinin bilgisine değer verileceğini ${ }^{12}$ ortaya koyması açısından seçici olmak ${ }^{13}$ son derece önemlidir ${ }^{14}$. Aynı haberi farklı televizyon kanallarından izleyebileceğiniz gibi, internetteki farklı kaynaklardan da aynı bilgileri irdeleyebilirsiniz. Bunun dışında, yönetici olmanın getirdiği sorumluluk ise daha farklı bir düzeyde durmaktadır. Elinizdeki bilginin başkalarına gerekebileceğini düşünerek paylaşır ya da size gelen bir iletiyi başkalarına da iletirseniz bu sorumluluk altındasınız demektir.

Buradaki en önemli sorunlardan biri, bireylerin pandemi sürecinde yalnızca bilgilenmekle kalmamaları, bilgiyi yayan bir işlev de yüklenmeleridir. Bu bağlamda resmi açılamalardan özürlere kadar varan bir çizgide medyanın çok yönlü yapısının ${ }^{15}$ sürekli dinamik özellikler sergilemesi önemlidir. Olguların, olgular hakkındaki görüş, düşünce, tutum ve tepkilerle asılsız haberlerin birbiri üstüne katmanlar şeklinde yığıldığı ve gerçeklerin görünmesini engellediği nokta da tam burasıdır. Tıpkı çözülmüş bir yumak gibi, ipliğin hangi kısmının iletişime katılanı hangi uca götüreceği belirsizdir. Geleneksel medyada da yanlış yayınlar, özürler ve hatta tekzipler söz konusu olabilir. Ancak, bunlar bir şekilde daha rasyonel bir ortamda yayıldığından daha hızlı açıklığa kavuşabilmektedirler. Sosyal medya ise, bireye en yakın mesafeden gerçekleşen kör atışlarla, bir şekilde daha etkin ve daha vurucu olabilmektedir. Medyanın sosyal medya ayağında herkesin üretme ve düşünce belirtme lüksünü fazlasıyla rahat kullandığı ve paylaşma dürtüsü, mizah ya da politik sebeplerle bir şekilde asılsız haberlerin yayılmasına yardımcı olduğu göz ardı edilmemelidir.

11 https://www.hurriyet.com.tr/galeri-ingiltereden-turkiye-manseti-acil-tibbi-yardimgelmezse-41498790/4

12 https://www.iyigunler.net/guvenlik/bbc-turkiye-ingiliz-saglik-calisanlari-icin-malzemesatisina-h338313.html

13 https://www.cnnturk.com/dunya/ingiltereden-turkiyeye-tesekkur

14 https://www.haberturk.com/saglik-bakanligi-ingiliz-medyasinda-cikan-o-iddiya-yanitverdi-2671562

15 http://www.eurovizyon.co.uk/dunya/ingiliz-bakandan-turkiye-ye-tibbi-yardimtesekkuru-h67097.html 


\subsection{Katıştırma (Thread)}

Katıştırma kategorisi söz konusu olduğunda, bir konuyu ele alırken ve kurmacayı oluştururken, başka hangi kavramların ve konuların ikincil ya da daha alt başlıklar halinde metine yerleştirilebileceği irdelenmektedir. Örneğin, televizyon yayın akışına yerleştirilen sosyal mesajlar, siyasal ya da ekonomik düzleme ilişkin göndermeler, metin içi ve metin dışı referanslar, metinlerarası geçişler gibi noktalar önem kazanmaktadır. İnternet söz konusu olduğunda, katıştırma kavramının siyasal ve ekonomik reklamları ve hatta propagandayı da içerdiği unutulmamalıdır. Açılan sayfada birden karşılaşılan konuyla az ya da çok bağlantılı reklamlar, pop-up türü bilgilendirmeler, en yakın eczane ya da aile hekimliğine yol tarifi veren uygulamalar da bu tür katıştırma örnekleri arasında verilebilir ${ }^{16}$.

Bankaların ve marketlerin açıldığı günlerde ortaya çıkan ateş ölçme, el dezenfenktanı kullanmadan marketten içeri girememe, sosyal izolasyon kurallarına uygun olarak 1,5 m aralıkla bekleme gibi kuralların uygulandığını gösteren haberler de bu tür katıştırma örneklerinin kullanıldığı haberler olarak değerlendirilebilir.

Çocuklarla ilgili olarak katıştırma haberlerinde, anne babasının hastaneden dönmesini bekleyen çocukların pandemi sürecindeki özlemlerinin yansıtıldığı haberler, polis olan babalarına çizdikleri resimlerle sevgilerini yollayan kardeşlerin öyküleri de katıştırma örnekleri olarak ele alınabilir.

Pandemi kıskacındaki dönemde bireylerin ve toplumların medyaya daha fazla yöneldikleri ve bunun iki farklı temel arayıştan kaynaklandığı söylenebilir. Bunlardan ilki, 'bilgilenme' diğeri ise 'eğlenme-rahatlama' ihtiyacına dayanmaktadır. Bilgilenme konusu son derece önemlidir çünkü bilgi arasına katıştırılan görüntüler, küresel çapta çok geniş yankı uyandırabilecek ve derin etki bırakabilecek şekilde akmaktadır. Bu görüntüler arasında Covid'in farklı ülkelerde insanları nasıl sevdiklerinden ayırdığı, nasıl kimsesizler mezarlığına gömülmeye kadar varan bir çaresizliği beraberinde getirdiği, nasıl izolasyon ve sağlık şartları gerektirdiği, sağlık personeli ya da malzemesi yetersizliklerinin olumsuz sonuçları gibi pek çok duygusal katıştırma söz konusudur. Çin'den gelecek olan sarımsakların pandemi sürecinde gümrükte alıkonduğuna ${ }^{17}$ ilişkin ekonomi haberlerinden, hangi fabrikaların kepenk indirdiğine ve kaç kişinin işsiz kaldığına ilişkin

16 https://www.milliyet.com.tr/gundem/son-dakika-i-saglik-bakanligi-sahte-internetsiteleri-ve-uygulamalari-acikladi-6217359

17 https://www.hurriyet.com.tr/ekonomi/koronavirus-etkisi-41442705 
haberlere kadar, hemen her konu katıştırmayı içerebilir. Bunlar aynı zamanda görsellerle birlikte kullanıldığında somutlaştırılmış, belli bir neden sonuç ilişkisine bağlanmış ve hatta istatistiklerle desteklenmiş çıktılara dönüşmekte, inandırıcılıklarını perçinlemektedirler.

Pandemi konusundaki yayınlara katıştırılan öğelerin, ekonomiden siyasete, coğrafyadan, magazine, ergenlikten yaşlılığa kadar hemen her konuyu içerdiğini belirtmek gerekir. 'Hangi hastalıklar COVID-19 riskini beraberinde taşıyor' gibi bir başlık bile, pandemi ile ilintilendirilen onlarca hastalık konusunda ayrı ayrı haberlerin oluşmasına neden olabilmektedir. Benzer şekilde, hangi yaş, hangi kan grubu, hangi il gibi arttırılabilecek farklı parametrelerin her biri ayrı bir haber potansiyeli taşımaktadır ve bunların her biri birer habere dönüşmektedir. Hangi ünlünün karantina dönemini nerede geçirdiği ile ilgili magazin haberleri yapılmakta, bunlar birbirleri ile karşılaştırılıp kıyaslanmaktadır. Sonuçta, yüzlerce kez okunan, yorumlanan, iletilip paylaşılan haberler, konunun özünden çok katıştırmalara ağırlık veren türde haberlerdir. Kısacası, COVID-19, hemen her türlü olgunun, durumun, toplumun ve günlük yaşamın içine girmiş ve orada kalmıştır.

\subsection{Konuşlandırma (Task)}

Bir metnin oluşmasından sonra, belli bir bakıș açısı çerçevesinde, bu metnin ihtiyacı olan bireylere ya da gruplara gönderilebilmesi gereklidir. $\mathrm{Bu}$ da metnin hedef kitlesine ya da belli bir medyaya belli bir biçimde konuşlandırılması, belli alıcılara belli görevler ve sorumluluklar yüklemesi anlamına gelmektedir. Bu konuşlandırmanın gereği olarak belki metnin belli biçimlerinin, dilinin, görünürlüğünün farklılaşması gerekebilir. Bu tür değişimler geçiren metnin incelenmesini ele alan bu bakış açısı çok ince detaylar sunabilir. Konuşlandırma, bir yandan gönderici ile bağlantılı bir kavram olarak görünürken, bir diğer yandan da alıcıya bağlı ve seçimlik bir noktada durmaktadır.

Medya okuryazarlığı açısından, metin ile karşılaşan izleyici, takipçi, okuyucunun kendisini metinle nasıl bir zeminde bir araya getirdiği önemlidir. Örneğin, metinle izleyicinin aynı düzlemde mi yoksa karşıt düzlemlerde mi durduğu önemlidir. İzleyici, metne inanmayıp metnin karşısında durabilir ya da metni görmezden gelebilir. Metinde geçen yapılması gereken şeyleri (örneğin sokağa çıkma yasağı, maske takılması zorunluğu) umursamayabilir. Metnin kendisine ulaşma yolundan dolayı (aninden gelen bir ileti, resmi kaynaklı olan ya da olmayan, güvendiği ya da güvenmediği bir haber kaynağından gelen ileti gibi) değerlendirmeler 
yaparak bu metni önemsemeyebilir. Bazen de iletinin içeriği nedeniyle panik olabilir ya da herkesle paylaşabilir. Sonuçta önemli olan, izleyici, okuyucu ya da takipçiye kadar ulaşan metnin, birey tarafından kendisiyle, eylemleri ve düşünce sistemi ile nasıl ilintilendirildiğidir.

Pandemi sürecinde devinen medya metinlerine göz atıldığında, bunların çoğunlukla otoriter bir söylem tarzını benimsediği ve sürekli olarak izleyicilere, takipçilere belli görevler ve sorumluluklar yüklediği görülmektedir. Örneğin, yurt dışındaki haberlerde, ölüm oranlarının artışı ile birlikte, kentin hangi bölgesine yeni mezarlıklar kurulabileceği konusu gündeme getirilmiştir ${ }^{18}$. Buradaki konuşlandırma, hızlı ve yoğun ölümler karşısında yerel hükümet yetkililerinin sorumluluklarının ortaya konulmasına dayandırılmaktadır. Ancak benzer biçimde, örneğin 65 yaş üstü kişilerin sokağa çıkabileceğinin ve aileden bir kişinin onlara eşlik edebileceğinin belirtildiği metinlerde de bu sorumluluk aile bireylerinin istekli kişilerine aktarılmaktadır.

E-okul söz konusu olduğunda, gerek öğretim gerekse sınav süreci çerçevesinde öğrenciler ve öğretim elemanlarının eğitim alma ve verme sorumluluğu gündemdedir.

Bir başka açıdan bakıldığında, makarnaya olan talebin artması nedeniyle makarnanın fahiş fiyata satılmasının önüne geçmek için alınan önlemler ve bu konudaki bilgilendirmelerin de konuşlandırmalar içerdiği unutulmamalıdir.

Pandemi sürecinde her televizyon kanalı, haber programı, açı oturum ya da söyleşi tipinde programlara uzman konuklar davet etmiş, bu uzmanlar da pandemi süreci ile ilgili görüşlerini toplumla paylaşmışlardır. Bu tür görüşlerin de medyada konuşlandırılması ve nasıl değerlendirilmesi gerektiği konusunda ayrıca yayınların olması dikkat çekicidir.

Belki de en önemli konuşlandırmalardan biri devlet eli ile yapılan haberler çerçevesinde asılsız haberler üreten merdiven altı medya kuruluşlarına ve botlara itibar edilmemesi gerektiği ile ilgili bildirimlerdir. Bu tür bildirimlerde, halktan resmi olmayan kurum ve kuruluşlardan ulaşan asılsız bilgilere itibar etmemeleri, bilgiyi doğru kaynağından almaları öğütlenmektedir. Bu da medya okuryazarlığı adına çok olumlu ve anlamlı bir konuşlandırma içermektedir.

Çocuk ve Medeniyet 2020/1
18 https://www.sozcu.com.tr/2020/dunya/son-dakika-new-yorkta-olum-adasi-coronadanolenleri-gommeye-basladilar-5738706/ 


\subsection{Karşıya Geçişler \& Kabuller - Eğilimler (Transfers \& Trends)}

Metnin tek başına var olması, neredeyse olanaksızdır. Bu yüzden metnin hedef kitleye ulaşması ile onlardaki değişimler, kabuller ya da eğilimler, alg1, tutum ve davranış değişimleri de gözlemlenmelidir. Tüm metinler, her ne kadar sınırlı ve kapalı imiş gibi görünseler de aslında açık metinlerdir. Zamanın etkilerine, farklı okurların yorumlarına ve yeni uyarlamalara açık olmaları, metinlerin okuyucu ile sürekli bir alışveriş içinde olmasını da gerekli kılar. Dolayısıyla metinlerin sundukları dünyanın okuyucuların dünyasına geçebilmesi, kabul görmesi ve bunun etkilerinin yeniden metne aktarılabilmesi metin ile toplum arasında sonsuz bir tekrarlar dizgesi oluşturmaktadır.

Pandemi sürecinde, ülkemizde, resmi bildirimler ve yetkin ağızlardan çıkan bilgilerin vatandaşlar tarafindan kabul edilmesi daha kolay ve olumlu gerçekleşmiştir. Ancak, diğer ülkelerde durum aynı değildir. Medyada sergilendiği kadarıyla pandemi sürecinde yurt dışı hükümet yetkilileri, yerel yönetimler ve uzmanlar arasında sonu gelmez tartışmalar olmuş, pek çok konu ise çözümsüz kalmış, sonuçta taraflar birbirlerini suçlamışlardır.

Pandemi sürecinde hangi medyanın daha yoğun kullanıldığı konusu sürekli gündeme gelmiş, geleneksel medya ile sosyal medya arasında karşılaştırmalar yapılmıştır. Şurası gerçektir ki, medyanın sunduğu bilgi ve belgelerin, durumların ve olguların karşıya geçişi ancak izleyici kitlesinin kabulü ve onaylama eğilimleri ile mümkün olabilir. Bu bağlamda, geleneksel medyanın etkileşimsiz oluşu, kabul ve eğilimlerin net olarak görülmesini engeller konumdadır. Bununla birlikte, her bir haber için beğen tuşunun olması, altına açık ya da rumuz ile yorum yazılabilmesi, geleneksel medyadaki bir haberin de sosyal medyada devinebilmesi gibi değerlendirmeler, geleneksel medyanın da kabuller ve eğilimler konusunda belirleyici olabileceğini ortaya koymaktadır. Yine de, sosyal medyanın kullanmakta olduğu daha belirleyici göstergeler vardır. Örneğin, son bilgilere göre, \#koronavirüs, \#covid19, \#covid, \#pandemi ve \#koronavirüssalgını gibi hashtag'lar oldukça popüler olmuş, influencer'ların toplam gönderi etkileşiminin ise 2,9 milyonu geride bıraktığı bulgulanmıştır. Pandemi döneminde sosyal fayda ve bilgilendirme içeriklerinin de önem kazandığı görülmekte, en çok \#evdekal hashtag'inin kullanıldığı belirtilirken, 480 bin gönderi 1,5 milyardan fazla etkileşim almayı başardığı vurgulanmaktadır ${ }^{19}$.

Çocuk ve Medeniyet 2020/1 19 https://pazarlamasyon.com/pandemi-doneminde-sosyal-medya-ve-influencer-pazarlama-
calismalari-artti/ 


\subsection{Karşılamalar (Transition)}

Metnin hedef kitlesi, metnin üretilmiş olduğu zaman dilimi içinde farklı, daha sonraki zaman dilimlerinde çok daha farklı bir biçimde metne ilişkin karşılamalar geliştirebilir. Karşılamalar, metin karşısında kitlenin takınmış olduğu duygudurum, davranış ve tepkilerdir. Örneğin belli bir haberin okunma, tıklanma sayısı, bu haberin nasıl karşılandığı ile ilgili bir gösterge olarak değerlendirilebilir. Bu haberin yorumları ayrıca ilgilenilmesi gereken bir alan ortaya koymaktadır. Haberin başkaları ile paylaşım hızı, sıklığı ve bunların başka hangi paylaşımlara yol açtığı da ayrı nitel veriler sunmaktadır. Özellikle halkla ilişkiler, reklam ve pazarlama kavramı çerçevesinden bakıldığında her haber yayılmak, bilinmek ve izleyicileri üzerinde belli bir etkiye erişmek amacıyla üretilmektedir.

Karşılamalar bir yandan herhangi bir metnin toplumsal boyuttaki yayılımı ve benimsenişi olarak algılanabilirken bir başka açıdan, bu metne ya da bildirime yönelik tepkiler ve eleştirilerin de göz önünde bulundurulması gerekmektedir. Konu olarak bugün pek de cazip olmayan bir hastalık ve ölüm imgesi söz konusudur. Tarihteki salgın hastalıkların o dönem toplumlarını ve yapılarını, işlevlerini, ekonomilerini ve göçlerini nasıl etkilediğini bugün daha iyi analiz edebilmekteyiz. Tıpkı bunun gibi, yaşanılan pandemi sürecinde de belli bir toplumun ya da farklı toplumların bu konuyu nasıl karşıladığı son derece önemlidir. Daha sonraki dönemlerde de bu tür metinlerin okuyucuların ilgisini çekip çekmeyeceği şüphelidir. Ölüm ve hastalıkla ilgili durumları, tepkileri, sokaklarda kokan cesetlerin hikâyesini kim dinlemek ister ki? Toplumun buna geliştireceği refleksler neler olacaktır? Bu açıdan bakıldığında bu çok satabilecek bir konu ya da durum değildir. Ancak, herkesin tehdit altında olduğu bir dünya kavramı geliştirildiğinde, bugünün toplumunda ve gelecekte de hala insanın içini acıtan bir noktada duracağı öngörülmektedir.

Çocuk konusuna odaklanıldığında, çocukların bu durumla ilgili yaşantıları, kendilerini bu yeni ve riskli duruma karşı nasıl konumlandırdıkları, konuya ilişkin değerlendirmeleri, geçmişe ve geleceğe ilişkin yorumları oldukça ilginç görünmektedir. Endişelerden en büyüğü, çocukların hastalıkla karşılaşmaları konusunda yoğunlaşmaktadır. Bu, tıpkı bir kasırga, deprem ya da sel felaketinden kurtulmak kadar mucizevi bir şey olarak görülebilir ve bu da aslında, yaşam boyu anlatılacak bir hikâye anlamına gelmektedir ${ }^{20}$.

Pandemi sürecinde çocuk aktörler, çocukla ilgili faktörler ve toplumun çocuğa, çocuğun topluma olabilecek olumsuz etkileri düşünüldüğünde, 
bunların başında fiziksel bir tehlikenin yer aldığını vurgulamak gereklidir. İlk bilgi ve bulgulara göre çocukların daha önceden oldukları aşılar ve geçirdikleri çocuk hastalıkları nedeniyle, COVID-19'a karşı bir bağışıklıkları olduğu bilgisi yayılmıştır ${ }^{21}$. Dünyanın hemen tüm ülkelerinde ve medyada vurgulanan haliyle, COVID-19'un çocuklara bulaşmadığı ancak çocukların virüsün yayılımında taşıyıcı bir rol üstlenebilecekleri konusunda uyarılar yer aldı ve daha sonra da bu konu ile ilgili önlemler ön plana çıktı. Genel anlamda okulların, anaokullarının kapatılması ve çocukların akranları ve toplumdaki 65 yaş üstü bireylerle karşılaşabilecekleri parklar ve oyun alanlarından uzaklaştırılmasına ilişkin tedbirler öncelikle bunu içermektedir. Bu noktada, çocukların aslında korunan, korumaya alınan bir noktada değil, tam tersine çocuklardan korunulması gereken bir noktada durdukları çok açıktır.

Toplumsal anlamda, çocuklar genelde ufak tefek, ihtiyaçları gözden kaçabilen ya da kolaylıkla gözden çıkarılabilen bir noktada durmakta olduklarından, felaketler, olumsuzluklar karşısında da yine en çok etkilenenler kategorisinde yer almaktadırlar. Çocukların biraz büyümeleri halinde genellikle aileleri onların kendi başlarının çaresine bakabileceklerini düşünmeye başlamaktadır. Örneğin Anadolu'da büyük kardeşlerin küçük kardeşlerine bakmaları gibi durumlarla ya da bir aile yükünü omuzlamış çalışan çocuklarla sıkça karşılaşılması bu yüzdendir. Ancak tüm bu ek sorumluluklar, gerçek anlamda başka riskleri de beraberinde getirdiğinden, kaybedilen çocuk olmaktadır.

Örneğin, başlangıçta, hastalığın çocuklara pek dokunmadığı, daha çok yaşlıları etkilediği söylendiğinde, belki çocuklar adına hemen sevinilmiştir. Ancak, bu dönemde pek çok çocuğun belki de en sevdiklerini kaybedebileceği ve bundan hayatı boyunca etkilenebileceği gerçeği göz ardı edilmiştir. Yetişkinler unutabilir, ama çocuklar unutmaz, hatta tüm detayları daha derin duyumsar. Çocuk, doğası gereği küçük olabilir ancak içinde bulunduğu durumu ve hemen tüm detayları birden kavrayabilme, sezebilme gücü olan bir varlık olduğu için, annesi, babası, büyükanne ve büyükbabası ile ilişkisini kaybedebilme, arkadaşlarını öğretmenini bir daha görememe tehdidi altında olduğunu kavramak çocuğu üzer. Sevdikleri olmadan nasıl bir yaşam sürebileceğini ise henüz kurgulayamayacaktır. Bu da çocukta derin bir kaygı ve endişe oluşturur. Buna bir de medyadan yayılan bilgiler eklendiğinde, çocuğun stresinin kaç kat arttığını tahmin etmek bile gerçekten zor olabilir. Çünkü, diğer tüm risklerden öte, zararsızmış

21 https://tr.euronews.com/2020/03/12/cocuklar-koronavirusten-neden-etkilenmiyor 
izlememeleri gereken pek çok şeyle karşılaşabilmekte, geçici ya da kalıcı travma ve stres yaşayabilecekleri pek çok görüntüyü belleklerine çoktan yerleştirmektedirler.

Dış dünyada neler olup bittiğini anlayabilme kaygısı güden yetişkinlerin, anne babaların pandemi sürecinde evde çoğunlukla medyayı ve olup biteni takip etme eğilimi gösterdiği ortadadır. Bununla birlikte, farklı yaşlardaki çocukların medyada dile getirilen tüm detayları anlayabilmesi, olayın bütünlüğünü kavrayabilmesi oldukça zordur. Bu nedenle, özellikle 3-5 yaş çocukları tüm söylenenler içinden yalnızca belli sözcükleri seçip aklında tutabilecek, neden sonuç ilişkisini henüz kuramadıkları için, kısa anlatılara odaklanacaklardır. İzlediklerinden ve dinlediklerinden akıllarında yalnızca küçük detayların kaldığını ve çocukların bu detayları kendilerince birleştirip kurgulayarak kendi gerçekliklerini yaratma eğilimlerini de unutmamak gereklidir. Örneğin, haberin birinde 900 kişi ölmüş dendiğinde, çocuk iki farklı unsuru bir arada algılayacaktır. Biri ölüm kavramı ve çocuğun dünyasındaki yıkıcı etkisidir, ikincisi ise sayısal bir kavramdır ve bunun çocuğun dünyasında ne kadar büyük bir çokluk oluşturduğudur. Çocuk için ölüm, yas, hastalık gibi konular hele hele bunlara en yakınlarının, en sevdiklerinin maruz kalabileceği düşüncesi onların minicik kalplerinde çok büyük kaygılar, korkular yaratır ve süreç uzarsa bunlar travmalara dönüşür; bunların zaman içinde kalıcı olabileceği de ortadadır. İşte bu yüzden, bir çocuğun bu tür haberleri görmemesi gerekir. Çünkü odak sayılar çocuklar için önemlidir, hem de böyle bir sayı özellikle ölüm kavramı ile birleştirildiğinde çocuk açısından çok korkunçtur. Benzer şekilde cenazelerin sokaklardan, evlerden toplandığı ile ilgili görseller, yakın ve uzak zamanda etkisinden kolay kolay kurtulunamayacak bir zarar verebilir çocuğa.

Bu örneklerden çıkarılacak sonuç, pandemi döneminde evde kalan çocukların acıya ve duygusal açıdan hiç de hazır olmadıkları kavramlara maruz kaldıkları gerçeğidir. Aslında, anne babaları ile evde kalıp birlikte zaman geçirmek için can atan çocukların, bu birliktelik gerçekleştiğinde bunu acı ile birlikte anımsamaları en büyük paradokslardan birini ortaya koymaktadır. Oysa evde kalmak, çocuk açısından yetişkinlerle ortak paydalarını bulup ortaya çıkarabilmeleri için önemli bir zaman dilimi sunabilirdi; birbirlerini daha iyi tanıyabilmeleri, birbirlerini keşfedebilmeleri, birbirlerine daha sıkı sarılabilmeleri ve ilgi alanlarını, kaygılarını korkularını anlayabilmeleri için kullanılabilmiş olsaydı, gerçekten yaşam boyu sürecek çok önemli bir yakınlığın temelleri atılmış olabilirdi. Ardından biraz zaman geçinde, anne babalar çocukları ile evde geçirdikleri bu dönemde kendilerini çıldıracak gibi baskı altında, yoğun, ne yapacağını bilmez bireyler olarak tanımlayacak, çocuklar ise anne babalarını sürekli 
öfkeli, kaygılı, anlayışsız ebeveynler olmakla suçlayacaktır ${ }^{22}$. Tıpkı, sosyal izolasyon döneminde evde birlikte kalıp birbirini daha çok görmeye başlayan çiftlerin boşanmalarındaki artış gibi ${ }^{23}$, bu da anne baba çocuk üçgeninde kırılmalara yol açan olaylar ya da kopuşlar anlamına gelebilir.

Ev ortamında yani çocuğun en güvende ve rahat hissetmesi gereken bir noktada kendini huzursuz hissetmesi, son derece önemli bir sorunu gündeme getirmektedir. Hastalık Kontrol ve Önleme Merkezleri (Centers for Disease Control and Prevention - CDC) tarafından yapılan çalışmalar çocukların sık sık ya da devamlı olarak strese maruz kalmaları durumunda (örneğin, ihmal, istismar, işlevsiz aile ya da aile içi istismar gibi olumsuz durumlarla karşılaştığında) ve yetişkinlerden yeterli destek alamadıklarında, beyin yapılarının gerçekten kısırlaştığını ve organ sistemlerinin zayıfladığını göstermektedir ${ }^{24}$. Sonuç olarak stresle yaşayan çocuklar hayat boyu sosyal ve sağlık problemleri riski altında oluyorlar. Üstelik bu tür sorunlar sadece belli bir etnik gruba ait veya yoksulluk çeken çocukları etkilemiyor. Her kesimden çocuklar bütün yaşamlarını etkileyecek olan yüksek OÇY (Olumsuz Çocukluk Yaşantıları) skoruna sahip olabiliyor.

Pandemi sürecinde, ev ortamında sürekli kalmanın getirdiği stresin yiyecek içecekle ortadan kaldırılmaya çalışılması da oldukça sık karşılaşılan bir durumdur. Bu dönemde, bireylerin evde kalmanın yüklediği sıkıntıyı sürekli atıştırarak azaltmaya çalıştığı görünür bir şekilde ortadadır. Gerek pandemi öncesinde gerekse sonrasında yapılan yiyecek harcamalarına bakıldığında, pandeminin beslenme kültürünü bir anlamda değiştirdiği de açık ve net olarak görülmektedir. Ipsos Hane Tüketim Paneli göz önünde bulundurulduğunda, 10 Mart tarihinde "Türkiye'de Koronavirüsü tespit edilmiştir" açıklamasından sonraki ilk hafta hanelerin alışveriş davranışlarında ilk tepki olarak stoklama eğilimi gözlemlenmiştir. Ancak bulgular, ikinci haftada (18-24 Mart); hanelerin alışveriş sepetlerinde en çok artış gösteren kategorilerin farklılaştığını ve atıştırmalık ürünlerin büyük bir artış gösterdiğini ortaya koymaktadır. 3. haftaya gelindiğinde ise tüketicilerin hane içi tüketim davranışlarında farklılıkların devam ettiği, turşu, dondurma, meyve suları, reçel-bal, gazlı içecekler, krem çikolatalar, pudingler ve çikolata kaplamalı atıştırmalıkların bu dönemde de yüksek artış gösterdiği görülmektedir. 'Bisküvi \& Kek, Süt, Çikolata Kaplama, Peynir

22 https://www.milliyet.com.tr/gundem/bosanmak-icin-basvuranlarin-sayisi-4-katartti-6182253

23 https://www.milliyet.com.tr/corona-virus-cin-de-bosanmalari-neden-arttirdi-molatik-14524/

24 https://www.dbe.com.tr/Cocukvegenc/tr/news/toksik-stres-ve-cocuk-gelisimi/ 
ve Makarna' kategorilerinde satın alma artışının ilk tepkiye göre ikinci ve üçüncü haftalarda daha yüksek oranda artış gösterdiği ortaya çıkmıştır. İlk hafta yalnızca \%13 paya sahip olan ev dışı yiyecek siparişlerinin daha sonraki haftalarda \%38'e kadar yükseldiği de görülmektedir.

Pandeminin ilk haftasında ilk tepki ile alımı artan kategoriler daha çok temel gıda ve dezenfekte ürünleri olmasına karşın, eve kapanma etkisi ile alışverişte ikinci dalga çerçevesinde artış gösteren kategoriler arasında 'cips, çikolata ve şeker' gibi atıştırmalık ürünler listede yer almaktadır. İlk tepki alışverişinde büyüme göstermeyen Gazlı Meşrubat, Çikolata, Bebek mamaları, Şeker ve Soslar ise son haftanın artış gösteren kategorileri olarak ön plana çıkmaktadır. Bütün bunlar, evde kalmanın getirdiği stresle baş etmek için abur cubura fazlaca yer açıldığı ve özellikle çocuklara yönelik yiyeceklerin satışının arttı̆̆ını göstermektedir. Tüm bu sonuçlardan, pandeminin yan etkisi olarak obezite ve diabet riski artmış, sağlıklı beslenmeyen çocuklar olarak karşımıza çıkacak gibi görünmektedir.

\subsection{Kavrama ve Karar Verme (Thinking)}

Sonuçta, metin ile metin okurlarının buluştuğu noktalardaki temel gereksinim bir kavrama ve karar verme sürecidir. Bu sürecin nasıl başlayacağı ya da ne tür bir yol izleyeceği son derece önemlidir. Örneğin, bir reklam filmini izleyen izleyicinin sözü edilen ürünün kendisi için ne kadar yararlı olduğunu ne zaman kavrayacağı ve bu kavrayışı ne zaman satın almaya dönüş̧türeceği gibi düşünce ve eylem odaklı değerlendirmeler söz konusudur. Satan düşüncenin tam olarak ne olduğunun kavranması uzun soluklu, artsüremli (diachronic) ve eşsüremli (synchronic) araştırmalar gerektirmektedir.

Pandemi sürecinde görülen odur ki, paylaşılan tüm bu bilgi ve olaylar, okuyucular, izleyiciler ve takipçilerle medya üzerinden ve medya yolu ile paylaşılmakta, bireysel ve toplumsal günlük medya kullanım düzeyini artırmaktadır. Bilgilenmenin sürekli bir dolayımla, devinimle, el değiştirerek ve medya aracılığı ile bireylere ulaşıyor olması, bilgiyi adeta ikinci el bilgi durumuna düşüren ve yeterince içselleştirilmesine, kalıcılaşmasına engel olan bir konumda durmakta olmasına karşın, risk faktörünün varlığı, tüm bilgilerin 'çok önemli' başlığı ile belleğimize kaydedilmesine neden olmaktadır. Çünkü her bilgi, hemen, her an başkalarına aktarılabilecek noktada, acil, günlü ve hareketli bilgidir. Tam da bu noktada medyanın

Çocuk ve Medeniyet 2020/1 "geçişimi" (transmedia) son derece önemlidir. Çünkü medya bir bireyden bir diğer bireye, bir toplumdan bir başka topluma, hatta bir medyadan bir diğerine sürekli dolaşmakta, bu dolaşım sırasında kayıplar ve kazanımlarla, 
artılarla ve eksilerle başka metinlere dönüşmektedir. Öykünün tamamı asla tek bir medya türünde ortaya çıkmamakta bu yüzden takipçiler sürekli bir şekilde her bir medyadan daha farklı bilgiler alınabileceğini düşünerek sürekli bir devinim içine girmektedirler. Örneğin, bir başka ülkenin gazetesindeki bir olay, ülkemiz gazetelerine neredeyse günü gününe aktarılabilmekte, gazetedeki yayın hakkında ise sosyal medyadan pek çok paylaşım gerçekleşebilmektedir ${ }^{25}$. Ülkemizde ve dünyada geleneksel medyanın mı yoksa sosyal medyanın mı daha hızlı ve etken olduğu, daha güvenilir ve kaliteli olduğu konusunda pek çok araştırma gerçekleştirilmiştir ${ }^{26}$.

\subsection{Katılım (Tailoring)}

Metin, açık uçlu bir değerler sistemidir. Bir metinle karşılaşan birey ya da gruplar, metine katılmaya başladıkları andan itibaren onunla ilgili kendilerine daha yakın gelen unsurları bir anlamda değişikliğe uğratır ve kültürel bir adaptasyon süreci yaşarlar. Metin, bizden çok farklı olmasına belki de yabancı kaynakları olmasına ve farklı bir coğrafyada geçmesine karşın metne katılım, o metnin onaylanması ve bize katılması anlamına gelmektedir. Bu bağlamda, metne katılım, duygusal olabileceği gibi, bilimsel, kurgusal, siyasal, ekonomik, toplumsal ya da kültürel de olabilmektedir. Bu bilgiler ışı̆̆ında, pandemi sürecindeki diğer tüm ülkelerdeki vakaların sanki yanı başımızda imiş gibi algılandığını, içimizi acıttığını, bizi de tıpkı izlediğimiz diğer insanlar kadar çaresizlik ve mutsuzlukla baş başa bıraktığını söylemek pek de yanlış olmayacaktır. Her bir ülkede yaşanan her farklı acı, derlenip toplanıp ekranları başında olan ve bu metne katılan tüm takipçilerin paylaştığı bir olgu ve duygu haline gelmektedir. Zaten, uzmanlar, medyanın sunduğu ikinci el deneyimlerin de tıpkı bireyin kendi deneyimleri gibi kimliğinin, benliğinin ve hatta anılarının bir parçası haline geldiğini kanıtlamışlardır. Buradan hareketle, ister yanı başımızdaki sokakta gerçekleşsin, isterse dünyanın öbür ucunda, pandemi yüzünden acı çeken herkesin acısının ortak bir acıya dönüştügüüü vurgulamak gereklidir.

Bu sürecin en önemli aktörlerini medya aracılığı ile toplumu ve toplumsal kuruluşları bilgilendiren uzman otoriteler (bakanlık açıklamaları, DSÖ açıklamaları), olayları gözlemleyip aktaran görgü tanıkları (hastalığa yakalananlar, hastalıkla savaşan hemşire ve doktorlar) ile tüm bu olup

\section{7}

Çocuk ve Medeniyet 2020/1
25 https://www.istanbul.edu.tr/tr/haber/prof-dr-gucdemir-kuresel-salgin-dijitalteknolojilere-bagimliligi-artirdi-500053005500360051004B00430061004600670033003 $9007900700046006200610041004 F 003200370077003200$

26 https://www.haberturk.com/pandemi-geleneksel-medyaya-guveni-artirdi-2654554 
bitenleri izleyen sıradan izleyiciler, okuyucular, takipçiler şeklinde kaba bir sınıflandırma ile sunmak mümkündür. Bütün bunların etkilerini ele alan haberlerin de sayısı oldukça fazladır. Her bir haberin anlık ve uyulması gereken yeni bilgiler içerdiği durumlar dışında, virüsün dünyanın diğer bölgelerinde nelere sebep olduğunu da önemseyen insancıl bir farkındalığın da geliştiğini vurgulamak gereklidir. Belirlenmiş olan bu küresel gündem ve tüm bu baş döndürücü aktarım hızı yalnızca yazılı bilginin değil, görsellerin de devinimini beraberinde getirmiştir. Örneğin boş sokakların, kentlerin, hastanelerin fotoğrafları, mezarlık ve defin fotoğrafları, üzgün ya da hasta insanların fotoğrafları gibi haber eşlikçisi pek çok görsel de bulunmaktadır. Çoğunlukla görsellerin altında yazan ülke isimleri de olmasa, bu görsellerin ne ifade etmesi gerektiğini çözmek bile oldukça güç görünmektedir. Hastalığın sürekli ve hızlı yayılımı, tanılama ve tedavi etme süreçlerindeki belirsizlikler de söz konusu olduğunda, dünyanın her yanındaki insanların kendilerini ne kadar umutsuz, çaresiz ve mutsuz hissettiklerini ve medyaya nasıl bağlanma gereği hissettiklerini vurgulamaya gerek yoktur.

\subsection{Kriz Çözümleri (Taking Risks)}

Her bir metin ve metindeki her bir imge aslında bir anlamda alımlayıcı tarafta kriz yaratan bir noktada durmaktadır. Bir yandan bu krizlerin nedeni olan metinler, bir diğer yandan da, yaratılabilecek krizleri öngörerek bunları göğüslemek, aşmak, çözmek durumundadırlar. Örneğin, anlatılar bireylere inandırıcı gelmeyebilir, ya da aynı alanla ilgili pek çok farklı anlatı ile karşılaşan bir birey, bunlardan birini seçmeye eğilimli olabilir. Belki de belli bir dünya görüşü çerçevesinde bakan, belli politik, sosyolojik, felsefi ya da ekonomik tarafta olan bireyler ve toplumlar, anlatıların kendi sistem ve bakış açıları ile uyuşmayan bölümlerini yadsıyabilir ya da görmezden gelebilirler. Bir bağlam, başka bir ülkede yeterince tutunamayabilir ya da maliyetli bir haber programı, istediği izleyici oranına ulaşamayabilir. Metinlerin kendi içlerindeki anlamlar ya da üretildikleri dönem, toplum ya da medya sorun ya da tepki yaratabilir. Kısacası, yaşamda risk her zaman vardır ve her zaman bir ya da birkaç krizin birden çözülmesi gerekebilir. Özellikle medya açısından değerlendirildiğinde, medyanın kendisi erişim riski, sürdürülebilirlik riski, kabul edilebilirlik riski, anlaşılabilme riski, dolaşımda kalma ya da kalmama gibi birçok riski beraberinde getirmektedir.

Medyanın pandemi sürecindeki en büyük risklerinden biri yok sayılma riski idi. Çeşitli araştırmalar amacıyla yüz yüze görüşmeler sırasında gerçekleşen paylaşımlar ya da anket çerçevesinde verilen yanıtlar, bireylerin sürekli felaket haberleri sunan bir medyadan uzaklaşmak istediğini ortaya 
koymaktaydı. Öyle ki, insanlar artık pandemi, izolasyon, dezenfekte, korona sözcüklerin duymak dahi istemiyorlardı. Medyadan kaçış yine medyaya doğru gerçekleşiyor ve izolasyon ortamında, çocukların zor zamanları atlatmak için kitap, müzik, bilgisayar oyunu gibi farklı medyaya yönelmeleri, belli bir medyanın istenilen bilgi, güven ve huzuru vermediği zamanlarda bir başka medyaya kaçış yolu olarak değerlendirildiğini ortaya koyuyor.

Pandemi sürecinde dışarı çıkamayan bireyler, tüm olup biteni ve gerçekleri medyadan öğrenebileceklerini düşündüler. Bu çok büyük bir yanılgıydı. Biliyoruz ki, medya yalnızca gerçekleri göstermiyor, manipülasyon, fabrikasyon, üretilen, asılsız, yalan ya da sahte haber yayılan bir ortamda olduğumuzun da farkında olunması gereklidir. Bu durumda anne babanın çocuğun yanında olarak olup biteni onunla da onun dilinde paylaşması ve medya güvenilirliğini sorgulaması gereklidir.

Çocukların, kendilerini rahatlatma aracı olarak medyadan yardım aldıkları bir gerçek. Türkiye bağlamında, bilgisayar ve internetin kendisini rahatlattığını düşünen çocukların oranı \%48'e, televizyon veya videoların kendisini rahatlattığını ifade edenlerin oranı ise \%54'e ulaşıyor. Çocukların \%68'i okuldan ve derslerinden geri kalmaktan ve \%69'u da okula yeniden geri dönememekten ve arkadaşlarını görememekten endişe ediyor. Arkadaşları ve akrabaları ile sosyal medya yardımıyla iletişimde olmanın verdiği rahatlık söz konusu olduğunda bu oran \%64'e kadar yükseliyor. Çocukların seçimleri genellikle dijital medyadan yana olduğunda, geleneksel medya ve yeni medya arasındaki çelişki ve rekabeti de gündeme getirmektedir. Genç nesil, dinamik yapısı ve tercihlere değer vermesi nedeniyle istenildiğinde işlevselleșen bir medyayı tercih ediyor gibi görünüyor.

\subsection{Kurallar ve Teknolojik Olanaklar (Technology)}

Her metin, içinde bulunduğu medya ile biçimlendirilirken, belli kurallara uymak ve farklı bir teknolojik süreçten destek almak zorundadır. Bu kurallar ve teknolojik dokunuşlar, metnin daha geniş yığınlara ulaşmasını sağlayabileceği gibi onun doğasını, değerlerini, hatta iletisini bile etkileyebilir. Bu açıdan bakıldığında, pandemi sürecinde yaşanan temel sorunlardan birinin her test ortamında olduğu gibi geçerlilik ve güvenilirlik olduğu ortaya çıkmaktadır. Her bir farklı toplumun kendine özgü geçerli ve güvenilir gördüğü medya tipi değişiklik gösterebilirken, farklı bireylerin, eğitsel ve sosyoekonomik katmanların da farklı seçimleri olabileceği de ayrı bir gerçektir. Çocukların medya okuryazarlık sorunlarının çözümü, anne babaların çocukların medya izleme saatlerini ve etkinlik türlerini 
kısıtlamaları gibi genel geçer medya diyeti önerileri, pandemi sürecinde adeta çöpe atılmış ve kulak ardı edilmiştir. Bu nedenle, özellikle de çocuklar medyanın olumsuz sayılabilecek pek çok etkisine maruz kalmış durumdadırlar. Var olan sağlıklı kuralların pek çoğu esnetilmiş durumdadır. Örneğin, erken yatıp erken kalkma konusunda titizlikle uyulan saat kurma alışkanlıkları, okulların tatil olması ve günlerin evde geçmesi nedeniyle askıya alınmış durumdadır. Özetle söylemek gerekirse, çocuk için izlediği her şey yaşamın modelidir ve çocuk kendini buna uyumlandırmaya çalışır. Ama yanlış şeyler izlerse, yanlış bir modelleme yapar. Örneğin çocuk sürekli kaygı ve endişe dolu iletilerin devindiği ve kendini sıkıştırılmış hissettiği bir evde sağlıklı düşünemez, sağlıklı gelişemez. Bu yüzden yetişkinlerin de medya kullanımlarına dikkat etmeleri gerekmektedir. Sonuçta, günlük rutinlerin devam ettirilmesi ve etkin/aktif kalma adına yapılması gerekenlerin çoğu yapılmamıştır. Anne babaların pek azı çocuklarının televizyon izleme ya da bilgisayar, cep telefonu kullanma alışkanlıklarını pandemi döneminde de kontrol altında tutmaları ve denetlemeleri gerektiğini anımsadılar. Oysa her zaman yinelenmesi gerektiği gibi, kaç yaşında olursa olsun, çocuğun medya ile yalnız başına bırakılmaması, denetlenmesi de son derece önemlidir. Medyanın belirli kavramları aktarmada bize yardımcı olmasını beklerken, çocukların yanlış şeylere yönelmelerine, henüz hazır olmadıkları düşünce ve kavramlarla hatta siber zorbalıkla karşılaşmalarına neden olabilmektedir.

Çocukların gece geç vakitlere dek medya ile iç içe olmalarına izin veren anne babalar, onların eğlendiklerini düşünerek en azından içlerini rahat tutmaya çalışmış görünmekteler. Oysa ki çocukların büyük bir çoğunluğu, özellikle de 9-13 yaş grubundakiler, yetişkin medyasından pek de iyi anlayamadıkları COVID-19 haberlerini kendi kaynaklarından araştırmaya çalışmakta, internette bununla ilgili daha fazla bilgiye ulaşmayı denemekteydiler. Araştırma sonuçlarından örnek verilecek olduğunda, COVID-19 konusundaki haber yayınlarının kendisini endişelendirdiğini ifade eden çocukların oranı \%62'ye ulaşırken, artık bu konudan sıkılmış olduğunu ve medyada COVID-19 ile ilgili bir şey görmek, duymak, okumak istemeyenlerin oranı \%48'e ulaşmaktadır. Çocuklar açısından, televizyon yayınlarının çocukların COVID-19 ile ilgili ihtiyaç duydukları tüm bilgileri sunduğunu düşünen çocukların oranı \%47 iken, korku ve endişenin dışında, çocuklar için hazırlanan medya içeriklerinin COVID-19'u anlatmasını ve onları bilgilendirmesini isteyen çocukların oranının \%62'yi geçtiği görülmektedir. Elbette çocukların gerçekçi bir biçimde ve bilinçli olarak aile tarafindan da bilgilendirilmesi gereklidir. Ancak bu, korkutucu bir 
biçimde gerçekleştirilmemeli, dışarı çıkmanın neden yasak olduğu, elleri neden dezenfekte etmek gerektiği, sokakta oynamanın getirebileceği zararlar çocuklara açıklıkla anlatılmalı elbette ancak çocukların hassas varlıklar oldukları da unutulmamalıdır. Belki de bu yüzden, verilen bilgilerle yetinmeyip, COVID-19 ile ilgili tüm bilgileri internette bulabildiğini ifade edenlerin oranı \%66'ya ulaşmakta, bu da çocukların, anlaşılabilir ve kendi yaşlarına, kendi hızlarına ve kendi ifade biçimlerine yakın bir medya arayışında olduklarını bir kez daha ortaya koymaktadır. Çocukların büyük bir çoğunluğu, aslında konuşulan dilleri bilmese bile yalnızca görsellerinden bir şey anlayabileceğini düşündüğü için yabancı kaynaklı film ve haberleri de gözden kaçırmak istemediklerini ve takip ettiklerini ifade etmektedir. Bunu, yalnızca pandemi çerçevesinde değerlendirmek de yanlış olabilir çünkü Türkiye'de Kore dizilerini büyük bir adanmışlıkla izleyen çok geniş bir genç izleyici profili de bulunmaktadır.

\subsection{Kayganlık (Transmedia)}

Bir metin, üretildiği ortamda kalıcı değildir, devinir, dönüşür, farklılaşır, eksilir ya da artar. Birey ve gruplar da zaman zaman neye, hangi medyaya ne zaman maruz kalacaklarını seçemez bir noktadadırlar. Çünkü hem metinlerin kaygan yapısı hem de medyanın geçişim özellikleri nedeniyle özellikle günümüzde kavramlar ve izleyicileri bir medyadan diğerine kayabilmekte, öykünün bir kısmını farklı bir kaynaktan edinmişken devamını geçişimli bir başka medya ile takip edebilmektedirler. Bu kayganlık özelliği metinlerin hedef kitlesini belirsizleştirip yığınlara dönüştürebileceği gibi her bir farklı medya çevresinde odaklanmış niş izleyicilerin oluşmasına da neden olabilmektedir. Kayganlık, zaman zaman tüm metinlerin bir arada görülebilmesine olanak tanımayabileceğinden, metnin iletisinin farklı katmanlara sunduğu farklı iletiler olması gerektiği de ortadadır.

Tüm bu kavramların medya akışı içinde yinelenme sıklığı ve hızı söz konusu olduğunda çocuğun bu durumdan etkilenmemesi olanaksızdır. Yani çocuk sıklıkla gördügüi iletileri daha iyi anlayabilmektedir ve onlara karşı bir duyarlılık geliştirecektir. Küçük yaşlardaki çocuklar için daha derin bir kaygı ve sevdiklerini kaybetme korkusundan söz edebilmek söz konusu iken, daha ileriki yaşlardaki çocuklar için sürekli gündemi takip etme, olup biteni yakalama korkusu gündeme gelecektir. Bu bir tür hastalığa bile dönüşebilir: FOMO denilen bu bir tür gündemi kaçırma korkusu söz konusu olduğunda, birey, diğerlerinin deneyimlediği şeylerden eksik kalma duygusu içindedir. arzusu bir araya gelir ve medya bağımlısı bir birey ortaya çıkar. 
Kayganlık kavramı pandemi sürecinde ele alındığında, çok değişik sonuçlarla karşılaşılabilmektedir. Pandemi niteliğinden dolayı küresel bağlamda oluşturulan uluslararası haber havuzundan çeviri yoluyla ulusal basına aktarılanlar yanında, il il, hatta ilçe ilçe yapılan haberlerle desteklenen ulusal perspektif, insanları sürekli medya izler durumda kalmaya itmiştir. $\mathrm{Bu}$, kalıcı ya da geçici bir FOMO durumudur aslında. Sürekli bilgilenme ve olup bitenlerden haberdar olma hali, insanların gece gündüz medya ile birlikte yaşamalarına ve bir medyadan diğerine sürekli yeni bilgi arayışı içinde devinmelerine neden olmaktadır.

Bu durum, daha önce bilinen ve yaşananlar ışığında yeni ve güncel bilgiler için sürekli izleyici, okuyucu ve takipçi konumunda kalmayı gerekli kılan, bireyin her an eyleme katılmaya hazır durumda bir oyuncu gibi tutulduğu önemli bir karşılaşmaya benzetilebilir. Hatta, bireyler, her gelen topa vurma alıştırmaları yapan oyuncular gibi, topla yani bilgi ile yalnızca çok kısa bir süreliğine karşılaşmakta ve onu hemen en yakınındaki arkadaşına pas vermek üzere göndermek zorundadır. Bu durumda, örneğin topların renkleri farklı ve arkadaşlarının konumları farklı bile olsa, oyuncu hangi topu hangi arkadaşına gönderdiğini anımsamakta güçlük çekebilir. Oyun süreci, sosyal izolasyon süreci uzadıkça, toplar sürekli ve belirsiz bir sıra ile geldiğinde hangi topu kime attığını ya da bu kararı nasıl verdiğini anımsayabilmesi artık kesinlikle mümkün olmayacaktır. Bu tür bir bilgi bombardımanının, insanların düşünce, tutum ve eylemlerinde nasıl bir değiş̧iklik ortaya çıkarabileceğine ilişkin güzel bir örnektir bu. Durumun alıştırma yapmanın dışında, gerçek bir oyun sürecinde, yani gerçekten bir risk içeren şartlar altında gerçekleşmesi ise birey üzerinde bambaşka etkiler ortaya çıarabilir. Özellikle, etkileşimli olduğu için sosyal medyadan ayrılmak istemeyen birey, hangi iletiyi beğenip beğenmediğini, hangisini hangi arkadaşları ya da grupları ile paylaştığını, en son neyi yayınladığını bile unutmuş, medyanın içinde kaybolmuş durumdadır. Bir yandan aslında içinde bulunduğu 'konfor alanı' içinde rahat ve korunaklı olduğunu düşünmekte, öte yandan ise bir adım sonra dışarıya çıkıp gerçekle ve hastalık hali ile yüzleşme ihtimali ile bir güven eksikliği hissetmektedir. Korku alanı adı verilen bu alandan, sorunların gerçek boyutlarını kavrayabileceği ve bunlarla yüzleşip baş edebileceği bir öğrenme alanına geçilmesi gerekmektedir ki, daha sonraki adımlarında amaçlarını saptayabilsin, hayallerini yaşama geçirebilsin ve kendini gerçekleştirerek gelişim alanını genişletebilsin. Ancak, bunları medya aracılığı ile gerçekleştirme çabaları pek de olumlu yanıt vermeyebilir. Çünkü medyayı her açtığında, yine kendini bastırılmış bir korku alanında

Çocuk ve Medeniyet 2020/1 bulacak, istatiksel ölüm oranları, yeni vakalar ve farklı ülkelerdeki pandemi süreçleri ile ilgili akan bilgiler, onu yeniden konfor alanına sıkışmaya zorlayacaktır. 


\section{Sonuç}

Artık 'Yeni Normal'i konuşmaya ve yaşamaya başladığımız şu günlerde, geçirdiğimiz döneme yeniden bir bakarak daha sağlıklı ve sağduyulu tanılar koymak mümkün gibi görünüyor. COVID-19 pandemi süreciyle ilgili Türkiye'de kamuoyu ve tüketicinin nabzı konusunda araştırma yapan Ipsos ${ }^{27}$, geçmişe, güzel ve mutlu günlere, sosyalleşmeye duyulan özlemin 5. Haftada en üst düzeye çıktığını ortaya koymuştur ${ }^{28}$. Ipsos'un araştırmasına göre her ne kadar endişe düzeyi yüksek olsa da vatandaşların evde kalmaya ancak birkaç ay daha dayanabilecekleri görülmektedir. Türkiye'de kamuoyunun \%70'i COVID-19 pandemi süreci bir süre sonra sona erse bile hayatımızın artık ciddi bir şekilde değiştiğini ve bir daha aslı aynı olmayacağını belirtiyor. COVID-19 öncesi dönemle kıyaslandığında bireylerin en çok istedikleri şeylerin başında sosyalleşmek geliyor.

Araştırma katılımcıları, en çok yürüyüş yapmak ve aile ve arkadaşlarla vakit geçirmek gibi sosyalleşme unsurlarını özlediklerini belirtiyorlar. Türkiye'de her 10 kişiden yaklaşık 8'i (\%79) kendilerinin veya ailelerinden birinin koronavirüse yakalanmasından endişe ediyor. Bu konuda kadınlar (\%89), erkeklere (\%69) oranla daha endişeliler. Endişe düzeyi yaş gruplarına göre incelendiğinde; en çok endişe edenlerin 36-45 (\%85) ve 46-55 (\%84) yaş aralığındaki bireyler olduğu görülüyor. Katılımcıların \%45'i COVID-19'un birkaç ay içinde kontrol altına alınacağını düşünüyor. Dörtte biri (\%24) ise normalleşmenin 6 aydan fazla bir süre alacağını belirtiyor ${ }^{29}$.

COVID-19 ile ilgili olarak kamuoyunun \%88'i televizyondaki haber programlarını haber kaynağı olarak belirtirken, \%63'ü de konuyu Sosyal Medyadan takip ettiğini ifade etmektedir. Alınan kamusal önlemlere destek oldukça yüksek görünmekle birlikte, dünyanın gelişmiş ülkelerinde yaşayanların birçoğu, COVID-19 karantina süreci sonlandığında ekonominin hızlı bir şekilde toparlanmasının olası olmadığını düşünmektedir. Araştırmaya katılan 15 ülkenin 10'unda insanların çoğunluğu, COVID-19 pandemi sürecinden kaynaklanan sosyal izolasyon ve karantina süreçleri sona erdiğinde ekonominin hızla toparlanacağı düşüncesine katılmamaktadır. Bu bilimsel veri; dünyada ekonominin toparlanma sürecinin geçici değil kalıcı bir dönemde etkili olacağını göstermektedir.

\section{3}

Çocuk ve Medeniyet 2020/1
27 https://www.ipsos.com/tr-tr/koronavirus-salginiyla-ilgili-turkiyede-kamuoyu-vetuketicinin-nabzi

28 https://www.ipsos.com/tr-tr/koronavirus-surecinde-kamuoyunun-nabzi-sosyallesmeken-ozlenen-durum

29 https://www.ipsos.com/tr-tr/koronavirus-salgini-ve-toplum-arastirmasi-4-donemdenone-cikanlar 


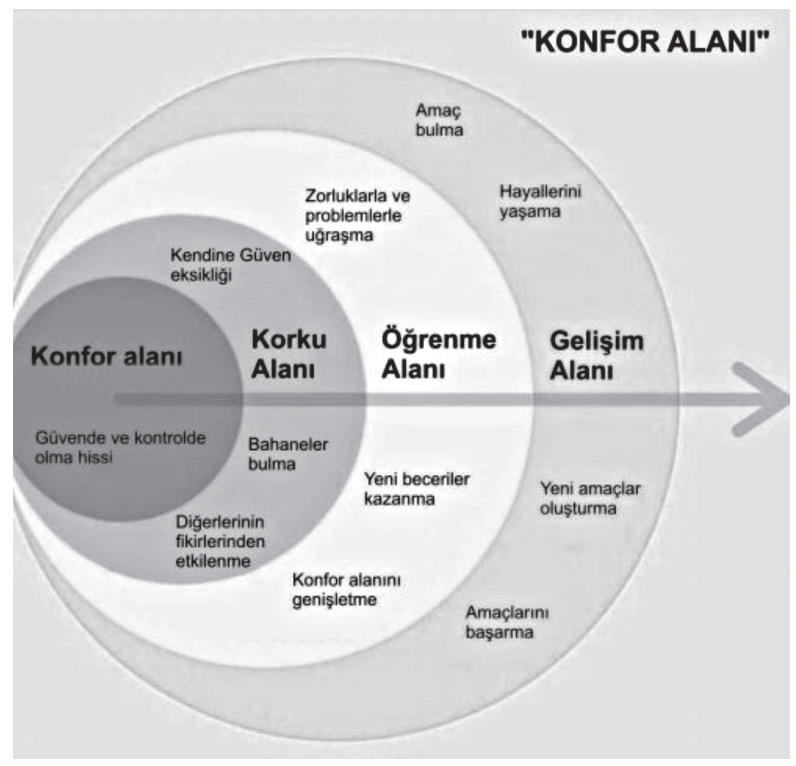

Şekil 1: Konfor Alanı (Kaynak: Brown, 2008)

9 - 12 Nisan tarihleri arasında yaklaşık 29.000 katılımcıyla gerçekleştirilen araştırmada; İspanya (\%76), Fransa (\%72), İtalya (\%68), İngiltere (\%67), Rusya ve Japonya (\%64) ve Kanada (\%62) hızlı bir ekonomik toparlanma olacağına katılmayan ülkeler arasında yer alırken; Vietnam (\%80), Çin (\%68) ve Hindistan (\%63) ise hızlı bir iyileşme gerçekleşeceğini düşünmektedir.

Pek çok kaynak, insanların izolasyon sürecini konfor bölgesinde olmak olarak nitelendirmektedir. Bununla birlikte, pandemi şartlarının pek de konfor alanı yarattığı söylenemez. Konfor bölgesi modeli, yeniliklere, maceralara, risklere açık bir toplum ile bu topluma ilişkin bir eğitim söz konusu olduğunda, alanyazında yaygındır (Brown, 2008). Brown bu modeli örneklerken, stresli bir duruma sokulan insanların ancak korkularının üstesinden gelerek ve böylelikle bir birey olarak büyüyecekleri inancına dayandırıldığını açıklar. Bu model, genellikle güçlü duygusal ve fiziksel tepkiler uyandıran yeni görevlerin (örneğin ip parkurları veya kaya tırmanışı aktiviteleri) kabullenilmesi ve uygulanması çerçevesinde, katılımcının yüksek bir biçimde algılayabileceği bir risk ve meydan okuma duygusu içeren etkinliklerden önce katılımcılara sunulabilir. Bu noktada bir metafor mu yoksa gerçek bir model olarak mı algılanması gerektiği de tartışmalıdır. Burada tam olarak istenilen şey, katılımcıların daha önceden içinde bulundukları ve kendilerini güvende hissettikleri konfor alanlarının 
dışına çıkarak, önceden belirlenmiş sınırlarını genişleterek ve yeni şeyler öğrenip yeni eylemler gerçekleştirerek (ve daha iyi, daha donanımlı bireylere dönüşerek) 'kendilerini aşmaya' teşvik edilmeleridir.

Piaget ve Festinger'in çalışmalarına dayanan, konfor bölgesi modelini destekleyen bilişsel ve sosyal psikoloji kuramlarını araştıran Brown, konfor bölgesinden çıkabilen bireyin, daha belirsiz ya da dengesizlik / uyumsuzluk durumlarını deneyimleyeceğini öne sürse de, bireylerin kendi fiziksel, sosyal, ekonomik, bilişsel ve duygusal sınırlarını aşmalarına teşvik etmek için risk kullanan bu modelin eğitim alanyazınında sürekliliği güçlü bir destek bulmamaktadır. Bu nedenle konfor bölgesi modelinin, yalnızca belli tip kısıtlı olgularda ve ortamlarda programlama ve pedagojiyi desteklemek için kullanılabileceği vurgulanmaktadır.

Örneğin, çocukların ya da gençlerin pandemi sürecinde yaşadıklarına bakarak kendilerine distopik bir gelecek çizmeleri, oluşturulan 'Kötü Dünya Sendromu'nun etkisi ile yerleşik bir dünya görüşü ya da yaşam tarzı oluşturulması en büyük risklerden biridir. Çok fazla medyaya maruz kalmanın bir sonucu olarak azalan okuma becerisinden ve hatta konuşma yitiminden ve yok olan yaratıcılıktan da söz edilebilir. Bu durumda anne babaların yapmaları gereken şey, çocuğa her zaman olduğu gibi 'ders çalış’ demek yerine onu daha iyi anlamaya çalışmak olmalıdır. Bu yeni dönemde, ailelerin düşük bir okul performansına ve alışık olmadıkları notlara da hazırlıklı olmaları gerekebilir. Çünkü pek çok çocuk bağlanma yaşadığı arkadaşlarını, öğretmenlerini göremediği, mahremiyetinin ve özel alanının (okulun) ve kendine özel zamanının elinden alındığı bir dönem geçirdi. Hatta bu dönem içinde kendi gibi davranamadı, bağırıp koşup oynayamadı ve özlemlerini isteklerini dile getirebilmek bir yana, derin korkular ve çaresizlikler hissetti. Tüm bunların elbette bazı sonuçları olacaktır. Çevrelerinde kendilerine destek veren, onları anlayan yetişkinler bulduklarında, çocukların pek çoğu bunu kolayca atlatabilir. Ancak bu destek ve anlayış esirgenirse, çocuk korkuları ve çaresizlik, güvensizlik duygusu ile baş başa bırakılır, anlayamadığı kavramlarla tek başına baş etmeye çalışırsa, bunun üstesinden gelmesi biraz daha zor olabilir ve zaman alabilir. Artık gündeme gelen 'Yeni Normal' kavramı ile birlikte, çocukların da acaba dışarıda ne olup bitiyor sorusunu bir yana bırakmaları, dışarıda onları ham yapmak için bekleyen canavarlar olacağı düşüncesinden kurtulup, korku odasından çıkmaları ve içe kapanmaktan vaz geçmeleri

Çocuk ve Medeniyet 2020/1 gereklidir. Pandemiyi sıklıkla ve ayrıntılarıyla anlattığımız kadar, çocuklara bu durumun geçici bir süreç olduğunu ve her şeyin artık normale dönmesi gerektiği de mutlaka anlatılmalıdır. 


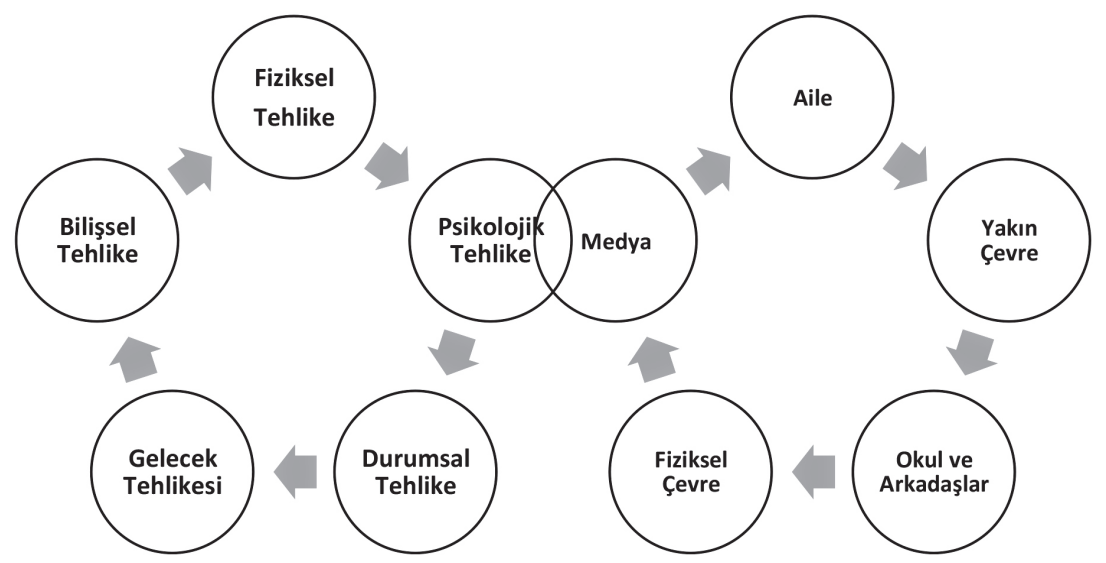

Şekil 2: Pandemi sürecinde çocukla ilgili risk alanları (Kaynak: Nilüfer Pembecioğlu 2020)

Çocukların pandemi sürecinde ne tür tehlikelerle ve yoksunluklarla karşılaştı̆̆ı ve yeni normale nasıl uyum sağlayabileceği konusundaki risk alanları aşağıda gösterilmektedir. Tehlikelerin pek çoğunun şu andaki pandemi sürecinden kaynaklı durumsal tehlikeler olduğu öngörülmektedir. Özetle belirtmek gerekirse, ne Türkiye'de ne de küresel ölçekte konu ile ilgili gerçek bir durum saptaması halen yapılmamıştır. Çocukların ne kadarı COVID-19 yüzünden aile bireylerini kaybetti, ne kadarı pandemi sürecinde aile büyükleri ile birlikte ya da onlardan ayrı yaşamak zorunda bırakıldı ve bu durumdan nasıl etkilenildi, halen bilinmiyor. Durumsal tehlikeler içinde, anne babanın işten ayrılmaları, birbirlerinden ayrılmaları, çocuğun yabancı bir ortama gönderilmesi, istismar edilmesi, parasal güçlük çekmesi, susuz ya da eğitimsiz kalması gibi pek çok durumla ilintilendirilebilecek tehlike sayılabilir.

Çocukların gelecekle ilgili kurgular gerçekleştirebilmeleri için güvenli, sağlıklı ve huzurlu bir ortamda yaşamaları gerektiği vurgulanmalıdır. Pandemi süreci, kısa bir süreliğine de olsa, bu süreci çocukların elinden almış görünmektedir. Medya yansımalarını göz önünde bulunduran çocuklar tıpla, hemşirelikle ilgili, aşı, araştırmalar, genetik gibi çeşitli alanlarla ilgili gelecek kurguları yapabilirler ya da bundan tümüyle vazgeçebilirler.

Önemli tehlikelerden biri çocukların içinde bulundukları bilişsel tehlikedir. Travma durumlarında çocukların bilişsel niteliklerinin zayıfladığı, gerilediği ya da bir daha geri döndürülemez nitelikte hasara uğrayabileceği söylenebilir. Çocukların bunca bilgi bombardımanı sonrasında kendilerini bilgiye kapatmaları bile olağan sayılabilir. Bu risk çemberi çerçevesinde 
Türkiye'de Corona Sürecinde Çocukların Medya Kullanım Alışkanlıklanı

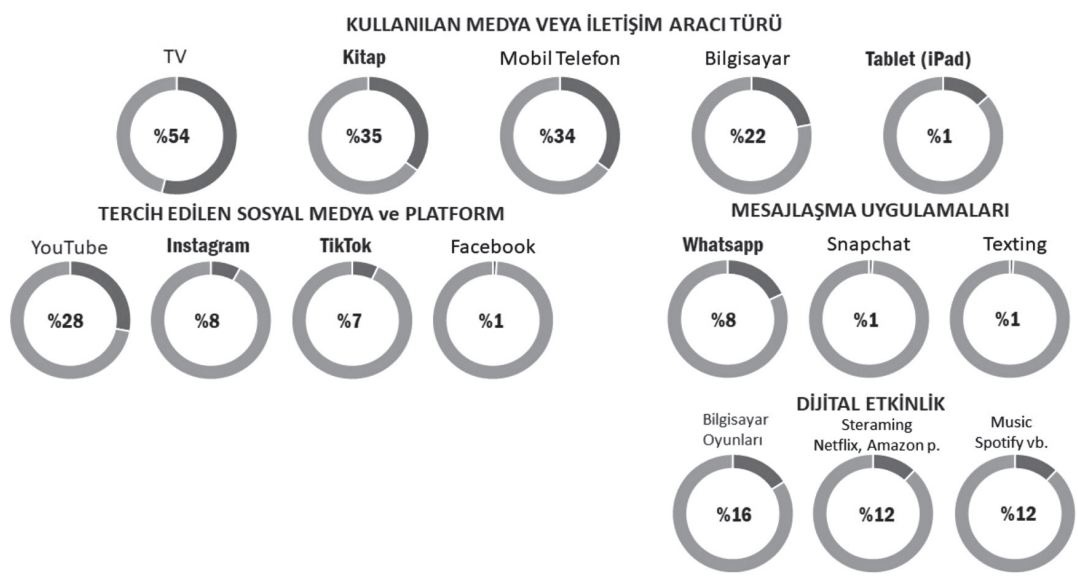

Şekil 3: Türkiye'de pandemi sürecinde çocukların medya kullanım alışkanlıkları (Kaynak: Nilüfer Pembecioğlu 2020)

en iyileştirici şeyin yine medya olabileceğine de dikkati çekmek gereklidir. Çünkü çocuklar kendilerini avutmak, kendilerini ve değerlerini yeniden keşfetmek için medyadan çok yardım alacaklar gibi görünmektedir. Aşağıda, pandemi sürecinde Türkiye çapında gerçekleştirilen bir araştırmada çocukların medya kullanım alışkanlıkları yer almaktadır. Bu oranlar, çocuğun daha çok televizyon yayınlarına maruz kaldığını göstermektedir.

Günümüz değerleri açısından bakıldığında, medya, bilginin, öğrenmenin, geleneğin, ailenin ve neredeyse tüm değerlerin yerini almış, bunların taşıyıcısı konumuna geçmiştir. Ailenin risk alanı ise, çocuğa istediği refah düzeyini sunup sunamaması, çalışan anne baba olup olmaması, maddi ve entelektüel açıdan çocuğu geleceğe taşıyabilecek bir vizyon ve misyon yaratıp yaratamaması ile bağlantılıdır. Çocukların \%50'si ebeveynlerin işe gitmiyor olmasını ve \%39'u ebeveynlerinin endişeli olmasını dert etmektedir. Verilere göre çocukların büyük bir çoğunluğu COVID-19 pandemi sürecinde evde kalmayı bir sorun olarak görmektedir. Eğitimlerine online olarak devam etmek pek çoğu için yeni ve eğlenceli olmasına karşın bu çocukların artık okula gitmiyor olmaları onların dünyasında iç karartıcı ve üzüntü veren bir noktada durmaktadır. Çocuklar ayrıca alışageldikleri arkadaş ve akraba ziyaretlerinden uzak kaldıklarını ifade etmekte ve göremedikleri arkadaşlarını, aile büyüklerini özlediklerini dile

Çocuk ve Medeniyet 2020/1 getirmektedirler. Daha önceden planlanmış etkinlikleri iptal edildiği ya da boş zaman etkinliklerine ve spora zaman ayıramadıkları için üzülenlerin oranı da oldukça fazladır. 
Yakın çevre, hem sıkça görüşülen aile bireylerini hem de komşuları ve fiziksel çevredeki diğer paydaşları kapsamaktadır. Çocuğun rutin görmekte olduğu kişiler söz konusu olduğunda örneğin servis şöförü, örneğin, yemek hizmetleri sunan kişi gibi aile dışı kişiler de hem birer iyileştirici hem de birer risk öğesi olarak sınıflandırılabilmektedir. Çocuğun bunlardan ne kazanabileceğine ya da onlar yüzünden ne kaybedebileceğine ilişkin risk tasarımları ayrıca tartışılmalıdır.

Okul ve arkadaşların da önemli birer etmen olduğu unutulmamalıdır. Çocukların \%56'sı evde oturup sıkılmayı sevmediğini ve anlık olarak uzak olsalar da \%68'i okulda ve sınıfta çok geri kalmaktan ve okula yeniden geri dönememekten endişe ettiğini dile getirmektedir. Fiziksel olarak ayrı olsalar da çocukların arkadaşlarını takip ettikleri; evcil hayvanlarının ve arkadaşlarının da hastalanabileceklerinden en az aile üyeleri kadar endişe ettikleri de saptanmıştır. Bu durumda okulun ve arkadaşlığın, ilgili öğretmenlerin ve öğrenme sevincinin çocuk üzerinde iyileştirici etkileri olduğu görülmektedir.

Genel anlamda çocuklar pandeminin başrol oyuncuları değildi ancak bu olgunun ve durumun en çok etkilenenleri arasında olma riski taşımaktadırlar. Açıkçası, onların fiziksel anlamdaki durumları söz konusu olduğunda kaç çocuğun evinde ve rahat, mutlu bir izolasyon süreci geçirdiğini, kaçının ise kendilerine dar gelen bir alanda, diğer kardeşleri ve aile yakınları ile odalarını ve fiziksel alanların belki de mahremiyetlerini paylaşmak zorunda kaldıklarını net olarak bilmiyoruz. Dışarı çıkamamanın getirdiği içsel sıkıntılar bir yana, bir de evin çocuklar için fazla kalabalık ve yetersiz olduğu durumlarda çocukların büyük tehlikelerle karşılaşabilecekleri de ortadadır. Artık yeni normalin gündeme geldiği şu günlerde bile pandeminin etkileri küresel çapta eşit bir dağılım göstermemektedir. Her ne kadar her bir ülke ellerin yıkanmasının gerekliliğini, sosyal izolasyonu ve maske kullanımını ön plana taşısa da hiçbir ülkede bunların yerine getirilebilmesinin altyapısının tam olarak bulunmadığını da ifade etmek gereklidir. Özellikle çocukların tek başınalığı ya da su kaynaklarına, eğitim kaynaklarına, sağlıklı ve sürdürülebilir ekonomik kaynaklara erişiminin kısıtlı olduğu bir dünya düzeni söz konusu olduğunda bu durum pek çok şekilde çaresizlikleri de beraberinde getirmektedir. Örneğin, Birleşmiş Milletler'in tahminine göre COVID-19 pandemisi nedeniyle 42 ila 66 milyon arasında çocuk aşırı yoksulluğa düşebilme riski taşımaktadır. Bu, tüm sağlık uyarılarına karşın pek çok çocuğun gerekli hijyen koşullarını taşıyan bir ortamda olmayabileceği, içme suyu, el yıkama suyu, sabun, dezenfektan ve maske gibi koruyucu unsurlara sahip olmayabileceği, hatta kendisi hasta olmasa bile hastalıkları olan diğer 
aile üyelerine bakmak zorunda olabileceğinin hep göz ardı edildiği anlamına gelmektedir.

Pandemi sürecinde, 188 ülkenin sosyal izolasyon tedbirlerine okulların kapatılmasını da eklemesi, okullaşma ve okuryazarlık oranları düşük olan pek çok ülke başta olmak üzere 1,5 milyardan fazla çocuğun eğitim süreçlerine ket vurdu. Okula gitmenin fiziksel sorumluluğundan kurtularak medya aracılığı ile açık öğretim haline getirilen okullaşma düşünce ve uygulamasının önünü açan eğitim platformları ise çocukların daha fazla medya kullanımına gerekçe hazırlamış oldu. Bununla birlikte çocukların medya erişilebilirlik oranlarında önemli artışların olduğunu, bu artışlardan en çok kız çocukların dijital teknolojilere erişiminin etkilendiğini söylemek mümkündür. Bu artışta, e-okullaşmanın önemi de çok yüksektir. Ayrıca, pandemi sürecinde, çocukların günlük uyku düzenlerinin ve ev içi yaşam düzenlerinin de bir anlamda bozulduğunu vurgulamak mutlaka gereklidir. Pek çok çocuk belki de, pandemi sürecinde kendisine yemek alabilecek bir aileye de sahip değildi, bir o kadarı da yetersiz beslenme koşulları altında yaşamaktaydı. Çalışan çocuklar, kimsesiz çocuklar, risk altındaki çocuklar da bunlara eklendiğinde, pandeminin aslında çocuklara zarar vermeyen bir seyir izlemiş olsa da gerçek anlamda çocukları vurduğu görülmektedir. Yetersiz barınma koşulları altındaki çocukların, ailesi çok kalabalık olan ve kendine ait bir odası, bir yatağı bile bulunmayanların dijital erişim aracılığıyla eğitiminin sağlanmasını beklemek de gerçekten çok iyiniyetli bir yaklaşım olarak değerlendirilebilir. Medyanın, etkilenim için kapılarını ardına kadar açmış olduğu bugünlerde, çocukların medyayı yalnızca eğitim amaçlı kullanmayabilecekleri, çeşitli siberzorbalık, kötü yazılım ve uygun olmayan içeriğe maruz kalabilecekleri de göz ardı edilmemelidir. Tehlikenin en büyüğü, zaten pandemi sürecinde medyadan yayılan görseller ile küçücük kalplere ekilen büyük korkulardır. Psikolojik tehlike ile vurgulanan, çocukların kendilerine ya da çevrelerine zarar verme eğiliminden, intihar eğilimine varabilecek denli geniş bir yelpazeye yayılmasıdır. Ölüm kavramı ve aileden birinin, aile büyüklerinden birinin hasta olabileceği, kaybedilebileceği korkusu, 'normalleşme' sürecinde birdenbire yok olabilecek bir şey değildir. Sonuç olarak, bu görüntülere maruz kalan çocukların büyük bir kısmı geçici ya da kalıcı olarak bir travma yaşamış, yaşamında hiç hazır olmadığı kavramlarla ve çaresizliklerle karşılaşmıştır.

Pandemi sürecini çok yakın da olsa, geçmişe dönüp değerlendirmek gerektiğinde, sürekli önerilmekte olan "Medya Diyeti”nin en çok da bu acil durum dönemlerinde tutulması gerektiği düşünülmektedir. Hem yetişkinler hem de çocuklar için bu diyet gerçekten çok önemliydi. Ancak, özellikle çocukların tüm ekranlardan uzak tutulmaları önerilmesine 
karşın, pandemi döneminde herkes ekran başındaydı. Yaşanan ya da yaşanabilecek olan travmaların pek çoğu medyanın çocuk psikolojisi üzerindeki olumsuz etkilerinden kaynaklanacaktır denilebilir. Yeni normal döneminde de günlük yaşantımız artık sürekli yayında ve dijital modda olacakmış gibi görünmektedir. Böyle bir durumda, ekran kullanımının kontrolden çıkması çok kolay olabilecek, çocukların kötü dijital alışkanlıklar geliştirebilmesi daha kolay gerçekleşebilecektir. Evde kalan çoluk çocuk herkesin daha da medyaya düşkünleştiği bu dönem, insanların çevrelerinde olup bitenleri bilmek, anlamak ve yorumlamak için daha çok medya ile zaman geçirdiği bir döneme dönüşmektedir. Ancak, bilinen birçok kaygı bozukluğu bilinmezlikle ilgili duyulan kaygıdan ve bir şeyin olmasını beklemekten kaynaklanmaktadır. Covid 19 olgusunda şu an makro düzeyde bunu yaşıyoruz ve yaşayacağız. Çok yoğun bir bilgilenme dönemi geçirilmiş olmasına karşın konu ile ilgili halen bilinmeyen pek çok detay araştırılmakta, bireyler ve toplumlar halen medyayı takip etme isteği ve eğilimi göstermektedirler. Sonuçta, insanın normal şartlarda zihinsel olarak bastırdığı veya kontrol edebildiği ölüm korkusu, pandemi döneminde şiddetlenip kontrol edilemez hale gelebilmekte, ölüm korkusunun uzantısı olarak da uykusuzluk, kâbus görme, sürekli virüsle ilgili görüntülerin ve felaket senaryolarının akla gelmesi, hastalığın kendisine ya da yakınlarına bulaşacağı konusunda endişe duyulması, kolay irkilme, çabuk sinirlenme, gelecek konusunda plan yapamama, ümitsizlik, yalnızlaşma, yabancılaşma, aşırı kaçınma gibi şikâyetler geçici ya da kalıcı olarak ortaya çıkabilmektedir.

Salgının çocuklar üzerindeki en yoğun psikolojik etkisinin belki de şu anda tam olarak tanılanamayacak olan akut stres bozukluğu ve toksik stres olduğu söylenebilir. Çünkü, etkilerin bazıları hemen görülebilen etkiler bazıları ise zamana yayılan bir nitelik göstermektedir. Bu tür stresin, kişinin kendinin veya yakınının ölümcül bir olayla karşı karşıya kalması sonucu çaresizlik, güvensizlik, yoğun korku ve endişe yaşaması olduğunu vurgulamak gereklidir. Diğer kültürlere kıyasla, ölümü daha sakin ve daha kolay kabullenen bir kültürden geldiğimizi söyleyebiliriz. Ancak pandemi sürecinde deneyimlenen ölümün kendisi değil, kaybetme korkusudur. Bu noktada ölmek değil, ölme biçimi de rahatsız edici biçimlerde özellikle yabancı medya tarafından gündeme getirilmiştir. İnsanların en sevdiklerine bile veda edemeden, görüşemeden sağlık ve güvenlik gerekçesi ile alıkonduğu, ya da peşinden üzülenleri, ardından uğurlayanları olmadan, kimsesizler gibi bir mezara konulduğu hatta başka kültürlerde, toplu mezarlar ölü yakmalar gibi insanın içini acıtan olaylarla hemen herkes karşılaşmış ve bundan etkilenmiştir. Üstelik, bu tür haberler bir kereliğine de karşımıza çıkmakla kalmamış, neredeyse hemen her gün bir ritüel gibi 
belli bir zaman diliminde sürekli yinelenen bir ivme kazanmıştır. Çocukların duygusal nitelikleri, kendilerine sunulanların hepsini almaya, duygusal açıdan özdeşleşme yaşamaya daha elverişli olduğundan, duydukları her bir haberle birlikte üzüldüklerini, öyküsünü duydukları insanlar kadar kendilerini çaresiz, güçsüz ve yenilmiş hissettiklerini de vurgulamak gerekir.

İletişimde de, eğitimde de modelleme (modelling), özdeşleşme (identification), ekimleme - yerleştirme (cultivation), gündem belirleme (agenda setting) gibi kuramlar çocuk üzerinden çalışır. Elbette, haberleri önemsemeyin ya da duyarsızlaşın, anlamı çıkmamalı buradan ancak tam da bu noktada "Gündem Belirleme" kavramından söz edilmesi gereklidir. Medyanın gündemi bellidir, ancak, en azından anne baba olarak çocuğumuzun ve evimizin gündemini kendimiz belirleyebilir, çocukları yaşlarına uygun olmayan görüntülerden ve seslerden uzak tutabiliriz. Ses, genellikle göz ardı edilen bir noktada durmaktadır ancak, aslında görüntü, görünen şey, somut bir şeydir, gerçektir, asıl korkulan ise görünmeyendir. Medya onca görünürlüğüne karşın, COVID-19'u topluma tam olarak göstermeyi başaramamış, belki de bunu kasıtlı olarak yapmamıştır. Sonuçta tüm medyadan gösterilen 'kırık aynalardan' oluşmuş bir büyük ayna görünümündedir ve her bir parça başka bir gerçekliği yansıtmaktadır ancak aynanın bütününe bakınca gerçek gerçeklik bir türlü görünememektedir.

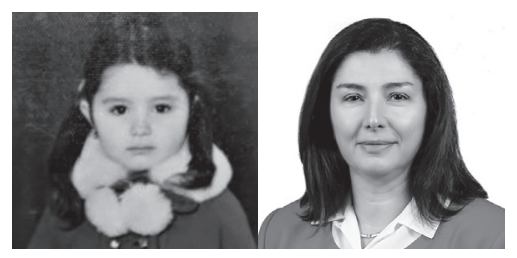

Nilüfer Pembecioğlu

\section{Kaynakça}

Brooks, S.K., Webster, R.K., Smith, L.E. et al. (2020). The psychological impact of quarantine and how to reduce it: rapid review of the evidence. Lancet. 2020;395(10227):912-920.

Brown, M. (2008). Comfort zone: Model or metaphor?. Journal of Outdoor and Environmental Education, 12(1), 3-12.

Damasio, A. R. (1992). Aphasia. New England Journal of Medicine, 326(8), 531-539.

Deighton J., Lereya S.T., Casey P., Patalay P., Humphrey N, Wolpert M. (2019). Prevalence of mental health problems in schools: poverty and other risk factors among 28000 adolescents in England. The British journal of psychiatry : the journal of mental science. 2019, 1-3.

Hossain, M.S., Sultana, A., Purohit, N. (2020). Mental health outcomes of Quarantine and isolation for infection prevention: A systematic umbrella review of the global evidence. psyarxiv.com/dz5v2/. Erișim tarihi Mayıs 2020. 
Loades, M. E., Chatburn, E., Higson-Sweeney, N., Reynolds, S., Shafran, R., Brigden, A., Crawley, E. (2020). Rapid Systematic Review: The Impact of Social Isolation and Loneliness on the Mental Health of Children and Adolescents in the Context of COVID-19. Journal of the American Academy of Child \& Adolescent Psychiatry.

Senek, S., Toz, H. (2019). Aytül Akal'ın masallarında günümüz çocuklarının yașadığı temel sorunlara yönelik iletiler. Türük Uluslararası Dil, Edebiyat ve Halkbilimi Araștırmaları Dergisi, (16), 217.

\section{Cevrimiçi Kaynakça}

http://uis.unesco.org/sites/default/files/documents/fs46-more-than-half-children-not-learningen-2017.pdf -21.09.2018 13:04

http://www.eurovizyon.co.uk/dunya/ingiliz-bakandan-turkiye-ye-tibbi-yardim-tesekkuru-h67097.html

http://www.gazeteilksayfa.com/dunya-genelinde-kovid-19-nedeniyle-olenlerin-sayisi-450-bini-asti76979h.htm

https://bit.ly/2NclOWU

https://pazarlamasyon.com/pandemi-doneminde-sosyal-medya-ve-influencer-pazarlama-calismalariartti/

https://tr.euronews.com/2020/03/12/cocuklar-koronavirusten-neden-etkilenmiyor

https://www.bbc.com/turkce/haberler-dunya-52224832

https://www.cnnturk.com/dunya/ingiltereden-turkiyeye-tesekkur

https://www.dbe.com.tr/Cocukvegenc/tr/news/toksik-stres-ve-cocuk-gelisimi/

https://www.haberturk.com/corona-virusu)

https://www.haberturk.com/pandemi-geleneksel-medyaya-guveni-artirdi-2654554

https://www.haberturk.com/saglik-bakanligi-ingiliz-medyasinda-cikan-o-iddiya-yanit-verdi-2671562

https://www.haberturk.com/son-dakika-koronavirus-salgininda-bugunun-yeni-vakasayisi-1467-2714597

https://www.hurriyet.com.tr/ekonomi/koronavirus-etkisi-41442705

https://www.hurriyet.com.tr/galeri-ingiltereden-turkiye-manseti-acil-tibbi-yardim-gelmezse-41498790/4

https://www.hurriyet.com.tr/gundem/37-bin-kisiye-mesafe-cezasi-41503013

https://www.ipsos.com/tr-tr/koronavirus-salgini-ve-toplum-arastirmasi-4-donemden-one-cikanlar

https://www.ipsos.com/tr-tr/koronavirus-salginiyla-ilgili-turkiyede-kamuoyu-ve-tuketicinin-nabzi

https://www.ipsos.com/tr-tr/koronavirus-surecinde-kamuoyunun-nabzi-sosyallesmek-en-ozlenendurum

https://www.istanbul.edu.tr/tr/haber/prof-dr-gucdemir-kuresel-salgin-dijital-teknolojilere-bagimliligiartirdi-500053005500360051004B00430061004600670033003900790070004600620061 $0041004 F 003200370077003200$

https://www.iyigunler.net/guvenlik/bbc-turkiye-ingiliz-saglik-calisanlari-icin-malzemesatisina-h338313.html

https://www.milliyet.com.tr/corona-virus-cin-de-bosanmalari-neden-arttirdi-molatik-14524/

https://www.milliyet.com.tr/gundem/bosanmak-icin-basvuranlarin-sayisi-4-kat-artti-6182253

https://www.milliyet.com.tr/gundem/son-dakika-i-saglik-bakanligi-sahte-internet-siteleri-veuygulamalari-acikladi-6217359

https://www.sabah.com.tr/yasam/2020/03/20/pandemi-nedir-neden-ilan-edilir-dso-tarafindanpandemi-ilan-edilen-hastaliklar-hangileri

https://www.sozcu.com.tr/2020/dunya/son-dakika-new-yorkta-olum-adasi-coronadan-olenlerigommeye-basladilar-5738706/

https://www.webtekno.com/turkiye-sahte-haberlere-en-cok-guvenen-ulke-oldu-h48103.html

\section{Nilüfer Pembecioğlu}

